\title{
Modelling impacts of acid deposition and groundwater level on habitat quality and plant species diversity
}

\author{
J. Kros ${ }^{1 *}$ D, J. P. Mol-Dijkstra', G. W. W. Wamelink', G. J. Reinds', A. van Hinsberg² and W. de Vries ${ }^{1,3}$
}

\begin{abstract}
Introduction: We quantified the effects of the site factors $\mathrm{pH}$ and nitrate $\left(\mathrm{NO}_{3}\right)$ concentration in soil solution and groundwater level on the vegetation of terrestrial ecosystems for the Netherlands in response to changes in atmospheric nitrogen ( $N$ ) and sulphur (S) deposition and groundwater level over the period 1990-2030. The assessment was made with the SMART2 model, a simple one-layer model including geochemical buffer processes, element cycling by litterfall, mineralisation and uptake, nitrogen transformation processes and element input through deposition, weathering and upward seepage.

Methods: To assess the effects of changes in abiotic site factors on the vegetation, we developed a simple plant diversity indicator for grassland, heathland and forest, based on the occurrence of target plant species and competing species. Species occurrence was calculated from the preferred ranges of each species for the $\mathrm{NO}_{3}$ concentration and $\mathrm{pH}$ in soil solution and mean spring groundwater level. Changes in the plant diversity indicator were assessed from effects of changes in the occurrence of target and competing plant species in response to changes in mean spring groundwater level and in $\mathrm{pH}$ and $\mathrm{NO}_{3}$ concentration, as calculated with SMART2. Calculations were made for combinations of five vegetation structure types (three forest types, semi-natural grassland and heathland) and seven soil types (three sandy soils, two clay soils, peat and loess soils) using a $250 \times 250 \mathrm{~m}$ grid. We used data for atmospheric deposition and groundwater level in the past to assess trends between 1990 and 2010 and evaluated two future scenarios for the period 2010-2030: a Business as Usual and an Improved Environment scenario.
\end{abstract}

Results: Comparison of model predictions on $\mathrm{pH}$ and $\mathrm{NO}_{3}$ with measured soil solution concentrations for forest showed a reasonable to good agreement for $\mathrm{pH}$ but rather poor for $\mathrm{NO}_{3}$. The largest impacts were found for the combination of the two Improved Environment scenarios.

Conclusions: Reductions in N and S deposition and an increase in groundwater level between 1990 and 2030 hardly caused changes in soil pH and only relatively small reductions in $\mathrm{NO}_{3}$ concentration (11-13\%). Nevertheless, those changes caused a significant increase in plant diversity indicator.

Keywords: Nutrient cycling, Soil modelling, Biodiversity, Acidification, Scenario analysis

\section{Introduction}

Changes in plant species composition are often caused by changes in site factors, such as $\mathrm{pH}$ and nitrogen inputs. There is ample evidence that increasing nitrogen (N) availability causes overall declines in plant species diversity (cf. Stevens et al. 2011; Bobbink et al. 2010; Bobbink et al. 2015). Abiotic site factors are affected by

\footnotetext{
*Correspondence: hans.kros@wur.nl

${ }^{1}$ Wageningen Environmental Research, Wageningen University and Research, P.O. Box 476700 AA Wageningen, The Netherlands

Full list of author information is available at the end of the article
}

changes in atmospheric deposition of sulphur (S) and $\mathrm{N}$ compounds (Galloway 1995), groundwater level changes (Van Wirdum 1991; Van Diggelen et al. 1996), changes in management and land use (Bakker 1989; Uuttera et al. 1996) and internal processes such as accumulation of organic matter and vegetation succession (Van Andel et al. 1993; Olff et al. 1997). Changes in abiotic site factors may affect the structure and functioning of semi-natural ecosystems such as grassland and heathland communities and thus the biodiversity (cf. Bobbink and Heil 1993; Tilman 1993; Stevens et al. 2004). N deposition has been 
affecting $\mathrm{N}$ availability for plants, soil $\mathrm{pH}$, nutrient availability, plant growth and distribution (cf. Dale et al. 2001; Pärtel 2002; Smart et al. 2005; Theurillat and Guisan 2001; Wamelink et al. 2005). According to Sala et al. (2000) and Xiankai et al. (2008), N deposition is the third most important driver of biodiversity loss after land use change and climate change and the most important driver for northern temperate forests. Often, ecosystems are affected by various threats simultaneously (multiple stress effect); whereas, environmental effects on ecosystems are usually studied for one stress factor at a time.

Two types of effects of enhanced atmospheric deposition of $\mathrm{N}$ and $\mathrm{S}$ can be distinguished: (i) (soil) acidification, leading to enhanced leaching of base cations, and increased dissolution of potentially toxic aluminium (Al) (cf. Van Breemen et al. 1982; De Vries et al. 1995), and (ii) eutrophication due to $\mathrm{N}$ enrichment causing an enhanced growth of nitrophilous species outcompeting other species. Increasing $\mathrm{N}$ availability and/or nitrate $\left(\mathrm{NO}_{3}\right)$ concentration often causes an overall decline in plant species diversity (Tilman 1987; Bobbink et al. 1998; Stevens et al. 2004; Aerts et al. 2003) even at longterm low $\mathrm{N}$ inputs (Clark and Tilman 2008). In some cases, especially under very nutrient-poor conditions, however, an increase in plant species diversity has been observed due to the expansion of nitrophilous species (Emmett 2007). Research on pine and spruce forests indicated that increased nitrogen inputs cause high concentrations of ammonium $\left(\mathrm{NH}_{4}\right)$ and $\mathrm{NO}_{3}$ in the soil solution (Roelofs et al. 1985; Kleijn et al. 1989), associated with a shift towards nitrophilous grass species in the forest understory (Hommel et al. 1990). $\mathrm{pH}$ decrease may also affect the plant species diversity in both short vegetation and forests. In general, acidophilic and eutrophic species increase at the cost of more sensitive species (Bobbink et al. 1996; Bobbink et al. 2015). Generally, the plant species that contribute most to biodiversity tend to grow on soils with a relative high $\mathrm{pH}$, low $\mathrm{N}$ content and low aluminium ( $\mathrm{Al}$ ) to calcium $(\mathrm{Ca})$ ratio (Bobbink et al. 1998; Bobbink et al. 2015).

In the Netherlands, many valuable vegetation types depend on shallow groundwater levels. In former times, the species belonging to these vegetation types have suffered severely from lowering of the groundwater level by intensive drainage and groundwater abstraction (Van Amstel et al. 1989; Runhaar et al. 1999). In addition, Hendriks (1994) showed that 29\% of the Dutch forests suffer from drought. Decreased upward seepage also adversely affected species diversity in many wetland ecosystems (Van Wirdum 1991; Runhaar 1999).

To evaluate the effects of eutrophication, acidification and drought on species diversity, several dynamic multispecies models in combination with dynamic soil vegetation have been developed that are presently explored in Europe (De Vries et al. 2010). One of those models is soil acidification model SMART (De Vries et al. 1989) that has been further developed to a soil acidification and nutrient cycling model, SMART2, predicting changes in soil and soil solution chemistry, as described in this paper. We validated the results of SMART2 by comparing modelled soil solution chemistry based on a national scale application with observations in a country-wide inventory near 1990 in the Netherlands. Furthermore, we predicted national scale changes in both soil solution chemistry and related plant species diversity using field-based empirical relationships of plant species composition as a function of $\mathrm{pH}, \mathrm{NO}_{3}$ concentration and groundwater level. The predictions were made for various scenarios with expected changes in atmospheric $\mathrm{N}$ and $\mathrm{S}$ deposition and groundwater level to assess the effectiveness of the combination of deposition reductions with water conservation measures.

\section{Methods}

The overall methodology (see Fig. 1) consisted of a linkage of the process-oriented soil vegetation model SMART2 (see "The SMART2 model" section) with a statistical based plant diversity indicator approach (see "The plant diversity indicator" section), using a nationwide parameterisation (see "Parameterisation and validation data" section) to assess the impact of two deposition and two hydrology scenarios (see "Deposition and hydrology scenarios" section) on plant species diversity.

\section{The SMART2 model}

SMART2 is a single-layer soil acidification and nutrient cycling model. It includes the major hydrological

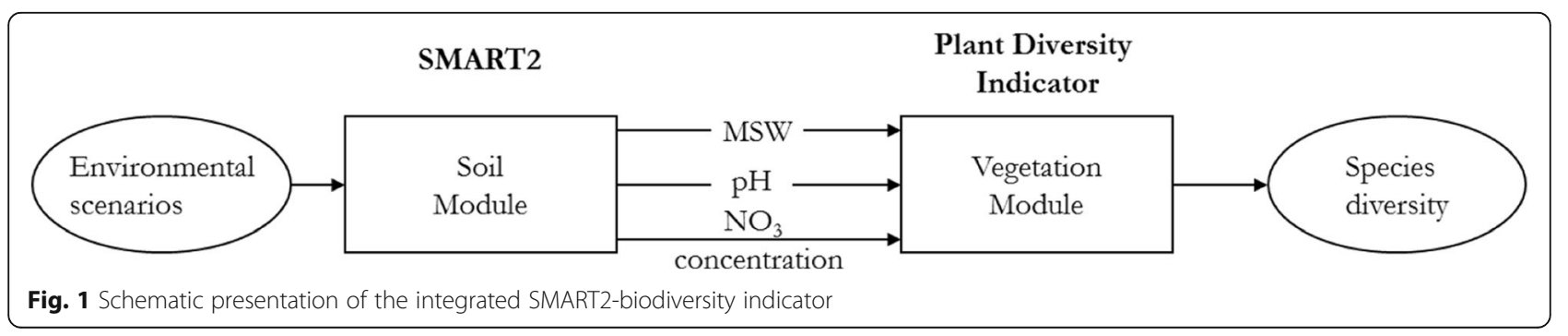


and biogeochemical processes in the vegetation, litter and mineral soil. The model simulates changes in proton $\left(\mathrm{H}^{+}\right)$, aluminium $\left(\mathrm{Al}^{3+}\right)$, divalent base cations (BC2, i.e. the sum of calcium, $\mathrm{Ca}^{2+}$, and magnesium, $\left.\mathrm{Mg}^{2+}\right)$, potassium $\left(\mathrm{K}^{+}\right)$, sodium $\left(\mathrm{K}^{+}\right)$, ammonium $\left(\mathrm{NH}_{4}^{+}\right)$, nitrate $\left(\mathrm{NO}_{3}^{-}\right)$, sulphate $\left(\mathrm{SO}_{4^{2-}}\right)$, chloride $\left(\mathrm{Cl}^{-}\right)$, bicarbonate $\left(\mathrm{HCO}_{3}^{-}\right)$and organic anions $\left(\mathrm{RCOO}^{-}\right)$concentrations in the soil solution. In addition, it simulates changes in solid phase characteristics connected to the acidification status, i.e. carbonate content, base saturation and amorphous Al precipitates. The SMART2 model consists of a set of mass balance equations, describing the soil input-output relationships, and a set of equations describing the rate-limited and equilibrium soil processes. SMART2 is an extension of the SMART model (De Vries et al. 1989). SMART2 is a one-layer model including geochemical buffer processes such as weathering, cation exchange and sulphate adsorption, nutrient cycling, including litterfall, mineralisation and uptake and a simple water balance, including runoff, upward and downward solute fluxes. Figure 2 gives a schematic representation of the SMART2 model and the included processes are summarised in Table 1. Details on the process descriptions, including the various input and interaction fluxes, are given in the Additional file 1, with an explanation of the symbols used in Additional file 1: Table S1.
SMART2 was constructed using a process-aggregated approach to minimise input data requirements for applications at a national scale. Therefore, various ecosystem processes have been limited to a few key processes represented by simplified conceptualisations. The soil solution chemistry in SMART2 depends solely on the net element input from the atmosphere (deposition), groundwater (upward seepage), nutrient cycling processes (uptake, litterfall, mineralisation and immobilisation) and the geochemical interaction in the soil ((de)nitrification, $\mathrm{CO}_{2}$ equilibria, weathering of carbonates, silicates and/or $\mathrm{Al}$ hydroxides and cation exchange). Processes not taken into account are (i) N fixation and $\mathrm{NH}_{4}^{+}$exchange, (ii) uptake, immobilisation and reduction of $\mathrm{SO}_{42^{2-}}$ and (iii) complexation of $\mathrm{Al}^{3+}$ with $\mathrm{OH}^{-}, \mathrm{SO}_{4^{2-}}$ and $\mathrm{RCOO}^{-}$.

Soil interactions are either described by simple ratelimited reactions (e.g. uptake and silicate weathering) or by equilibrium reactions (e.g. carbonate and $\mathrm{Al}$ hydroxide weathering and cation exchange). Influence of environmental factors such as $\mathrm{pH}$ on rate-limited reactions and rate limitation of weathering and exchange reactions are ignored. Solute transport is described by assuming complete mixing of the element input within one homogeneous soil compartment with a constant density and a fixed depth (representing the root zone). Because

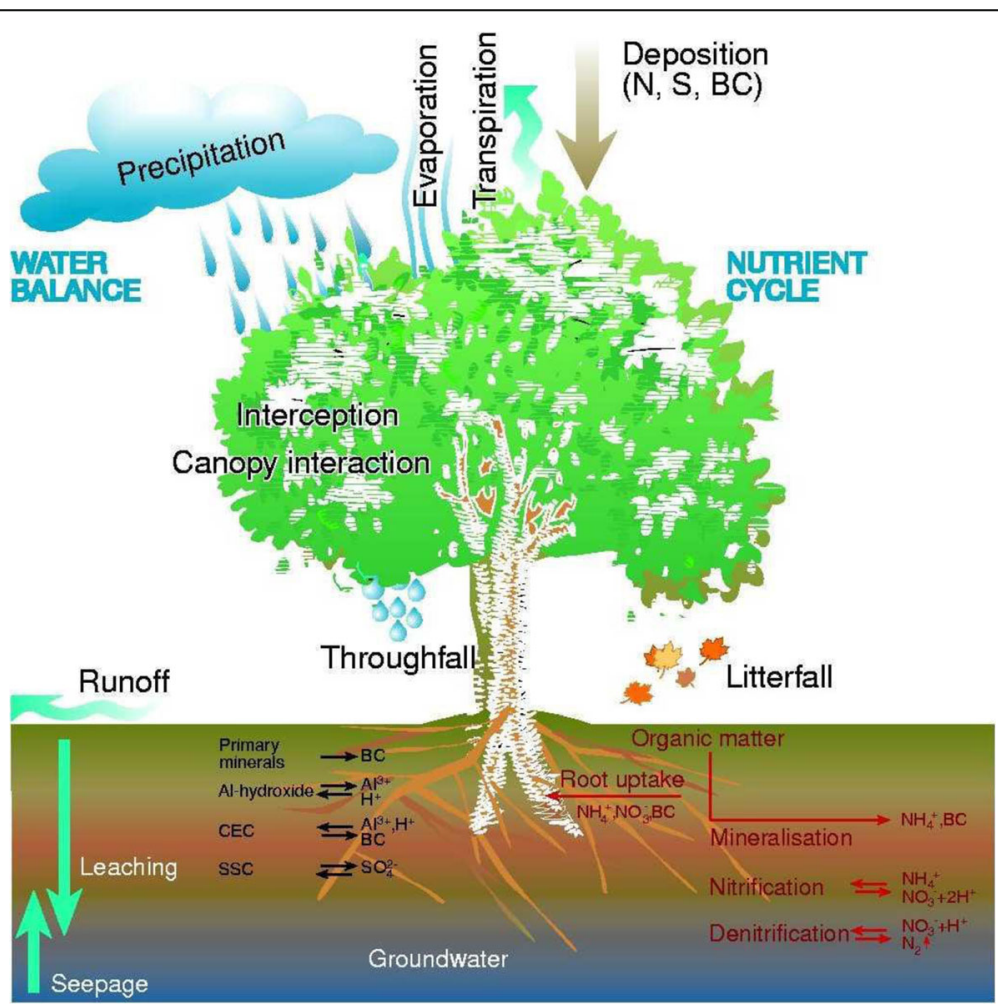

Fig. 2 Schematic representation of the processes include in the SMART2 model 
Table 1 Overview of processes included in SMART2

\begin{tabular}{|c|c|c|}
\hline Process & Element & Process description \\
\hline \multicolumn{3}{|l|}{ Inputs: } \\
\hline \multirow[t]{2}{*}{ Total deposition } & $\mathrm{SO}_{4^{2-}}, \mathrm{NO}_{3}^{-}, \mathrm{NH}_{4}^{+}$, & Inputs; total (wet and dry) deposition fluxes \\
\hline & $\mathrm{BC}^{2+\mathrm{a}}, \mathrm{Na}^{+}, \mathrm{K}^{+}$ & Element- and vegetation-dependent filtering factor ${ }^{b}$ \\
\hline \multirow[t]{2}{*}{ Upward seepage } & $\mathrm{SO}_{4^{2-}}, \mathrm{NO}_{3}^{-}, \mathrm{NH}_{4}^{+}$, & Inputs \\
\hline & $\mathrm{BC}^{2+\mathrm{a}}, \mathrm{Na}^{+}, \mathrm{K}^{+}$ & \\
\hline Water Balance & - & Inputs: precipitation, upward seepage, evapotranspiration \\
\hline \multicolumn{3}{|l|}{ Rate-limited reactions: } \\
\hline Foliar uptake & $\mathrm{NH}_{4}^{+}$ & Linear function of total deposition \\
\hline Foliar exudation & $\mathrm{BC}^{2+\mathrm{a}}, \mathrm{K}^{+}$ & Equals foliar uptake \\
\hline \multirow[t]{2}{*}{ Litterfall } & $\mathrm{BC}^{2+\mathrm{a}}, \mathrm{K}^{+}$ & Logistic growth \\
\hline & $\mathrm{NH}_{4}^{+}, \mathrm{NO}_{3}^{-}$ & \\
\hline \multirow[t]{2}{*}{ Root decay } & $\mathrm{BC}^{2+\mathrm{a}}, \mathrm{K}^{+}$ & Linear function of litterfall \\
\hline & $\mathrm{NH}_{4}^{+}, \mathrm{NO}_{3}^{-}$ & \\
\hline \multirow[t]{2}{*}{ Mineralisation } & $\mathrm{BC}^{2+\mathrm{a}}, \mathrm{K}^{+}$ & $\begin{array}{l}\text { First-order reaction and a function of } \mathrm{pH} \text {, mean spring } \\
\text { water level (MSW) and } \mathrm{C} / \mathrm{N} \text { ratio of the litter }\end{array}$ \\
\hline & $\mathrm{NH}_{4}^{+}, \mathrm{NO}_{3}^{-}$ & \\
\hline N immobilisation & $\mathrm{NH}_{4}^{+}, \mathrm{NO}_{3}^{-}$ & $\begin{array}{l}\text { Proportional to } \mathrm{N} \text { deposition and a function of the } \mathrm{C} / \mathrm{N} \\
\text { ratio soil organic matter }\end{array}$ \\
\hline \multirow[t]{2}{*}{ Growth uptake } & $\mathrm{BC}^{2+\mathrm{a}}, \mathrm{K}^{+}$ & Logistic growth \\
\hline & $\mathrm{NH}_{4}^{+}, \mathrm{NO}_{3}^{-}$ & \\
\hline Nitrification & $\mathrm{NH}_{4}^{+}, \mathrm{NO}_{3}^{-}$ & $\begin{array}{l}\text { Proportional to net } \mathrm{NH}_{4}^{+} \text {input and a function of } \mathrm{pH} \text {, mean } \\
\text { spring water level (MSW) and } \mathrm{C} / \mathrm{N} \text { ratio }\end{array}$ \\
\hline Denitrification & $\mathrm{NO}_{3}^{-}$ & $\begin{array}{l}\text { Proportional to net } \mathrm{NO}_{3}^{-} \text {input and a function of } \mathrm{pH} \text {, mean } \\
\text { spring water level (MSW) and } \mathrm{C} / \mathrm{N} \text { ratio }\end{array}$ \\
\hline Silicate weathering & $\mathrm{Al}^{3+}, \mathrm{BC}^{2+\mathrm{a}}, \mathrm{Na}^{+}, \mathrm{K}^{+}$ & Zero-order reaction \\
\hline \multicolumn{3}{|l|}{ Equilibrium reactions: } \\
\hline Dissociation/association & $\mathrm{HCO}_{3}^{-}$ & $\mathrm{CO}_{2}$ equilibrium \\
\hline Carbonate weathering & $\mathrm{BC}^{2+\mathrm{a}}$ & Carbonate equilibrium \\
\hline Al hydroxide weathering & $\mathrm{Al}^{3+}$ & Gibbsite equilibrium \\
\hline Cation exchange & $\mathrm{H}^{+b}, \mathrm{Al}^{3+}, \mathrm{BC}^{2+\mathrm{a}}$ & Gaines-Thomas equations \\
\hline Sulphate sorption & $\mathrm{H}^{+} \mathrm{b}, \mathrm{SO}_{4^{2-}}$ & Langmuir equation \\
\hline
\end{tabular}

${ }^{\mathrm{a}} \mathrm{BC}^{2+}$ stands for the sum of divalent base cations $\left(\mathrm{Ca}^{2+}, \mathrm{Mg}^{2+}\right)$

${ }^{b}$ Implicitly, $\mathrm{H}^{+}$is affected by all processes. This is accounted for by the charge balance

SMART2 is a single-layer soil model representing the root zone and neglecting vertical heterogeneity, it predicts soil solution concentrations of soil water leaving the root zone. The annual water flux percolating from this layer is taken equal to the sum of annual precipitation and upward seepage minus evapotranspiration. All water balance fluxes must be specified as a model inputs. The time step of the model is 1 year, so seasonal variations are not considered.

\section{The plant diversity indicator}

To evaluate the changes in soil biochemistry on plant species diversity, we developed a simple plant diversity indicator, based on the potential occurrence of plant species in. We examined four vegetation structure types (heathland, semi-natural grassland and deciduous forest), for which a list of target species and competing species were defined. The percentage of target species and the ratio of target species to competing species were used as indicator, with higher values being preferred. There are, however, other comparable models available describing the occurrence of plant species such as VEG (Belyazid 2006) and PROPS (Reinds et al. 2015). The later model uses the same principles and data as used in our plant diversity indicator, but it calculates the occurrence probability of plant species rather than a binary result on occurrence.

The potential presence of the selected species was based on the species preferences for soil $\mathrm{pH}, \mathrm{NO}_{3}$ concentration in the soil and the mean spring groundwater level (MSW) in the soil. For $\mathrm{pH}$, the measured $\mathrm{pH}-\mathrm{H}_{2} \mathrm{O}$ 
and for $\mathrm{NO}_{3}$, the measured $\mathrm{NO}_{3}$ content in $0.01 \mathrm{M}$ $\mathrm{CaCl}_{2}$ extraction was used. The preferences of the species were adapted from Wamelink et al. (2005, 2011). They calculated the ecological ranges for Dutch species based on soil measurements and groundwater level data (Wamelink et al. 2012). The abiotic data were combined with the present species and per species indicator values were calculated (Wamelink et al. 2005). The indicator values per species were used to estimate soil parameters of a training set of over 160,000 vegetation plots with unknown abiotic soil parameters. Subsequently, the range per species per abiotic parameter was calculated based on a (spline) response function, with using the 5 and 95 percentiles as limits of the response curve (for more details, see Wamelink et al. 2011).

For each vegetation structure type, a list of target species and competing species was defined, based on the Dutch habitat types as defined for the Natura 2000 sites (EZ 2012). The target species list contains the typical species of the habitat types. This list was completed with red list species (Bilz et al. 2011). The occurrence of red list species in the corresponding habitat was based on inventories of the habitat types from plots present in the Dutch vegetation database (Hennekens and Schaminée 2001). The competing species list, also based on the plots present in the database, including exotic species and species that are known to increase and outcompete other species under the influence of $\mathrm{N}$ deposition, such as Deschempsia flexuosa in heathland or Juncus effusus in grassland. The lists per habitat type were merged to the three vegetation structure classes modelled here, grassland, heathland and deciduous forest. This resulted in 122, 45 and 22 target species and 15, 27 and 23 competing species for grassland, heathland and forest respectively (see Additional file 1: Table S2). Thus, derived overall ranges are given in Table 2.
The abiotic soil conditions per site were simulated by SMART2. Output of SMART2 and the MSW from the hydrological scenarios were used as input to count how many target species and competing species could occur based on their ranges. When simulated $\mathrm{pH}, \mathrm{NO}_{3}$ concentration and MSW were all three within the ecological range of a species, that species was scored as expected to be present at the examined site. Per site, the number of target species, competing species and the ratio target species to competing species were totalized and then averaged for all examined sites per vegetation structure type.

Since SMART2 calculates the $\mathrm{NO}_{3}$ concentration and the $\mathrm{pH}$ in the soil solution, results were first transformed towards the nitrate content (in $\mathrm{mg} \mathrm{kg}^{-1}$ ) and the $\mathrm{pH}$ $\mathrm{H}_{2} \mathrm{O}$ (see Additional file 1).

\section{Parameterisation and validation data}

Data needed to apply SMART2 at a national scale, include system inputs (driving variables), the initial state of model variables and model parameters. System inputs refer to a specific deposition scenario and hydrology scenario for each grid cell. Model variables and parameters refer to particular combinations of soil types and vegetation structure types occurring in the Netherlands. We distinguished the following:

- Geo-referenced information on system inputs, for each grid cell, i.e. (i) soil type, vegetation structure type and MSW, (ii) the deposition of $\mathrm{SO}_{4^{2-}}, \mathrm{NO}_{3}^{-}$, $\mathrm{NH}_{4}^{+}$, base cations and $\mathrm{Cl}^{-}$(iii) precipitation and (iv) upward seepage fluxes.

- Generic information, i.e. mean values for initial values of model variables and model parameters for each combination of vegetation structure type and soil type.

Table 2 Ecological ranges (from 5 percentile, p5, to 95 percentile, p95) of the abiotic soil parameters for the abiotic response per ecosystem. Given are the median values of the p5 and p95 of the $\mathrm{pH}_{-} \mathrm{H}_{2} \mathrm{O}, \mathrm{NO}_{3}^{-}$content (in $\mathrm{mg} \mathrm{NO}_{3} \mathrm{~kg}^{-1}$ ) and mean spring water level (MSW, cm below surface) for the selected species

\begin{tabular}{|c|c|c|c|c|c|c|c|}
\hline \multirow[t]{3}{*}{ Ecosystem } & \multirow[t]{3}{*}{ Species type $^{a}$} & \multicolumn{2}{|c|}{$\mathrm{pH}-\mathrm{H}_{2} \mathrm{O}^{\mathrm{b}}$} & \multicolumn{2}{|c|}{$\mathrm{NO}_{3}^{\mathrm{b}}$} & \multicolumn{2}{|c|}{ MSW } \\
\hline & & \multicolumn{2}{|c|}{-} & \multicolumn{2}{|c|}{$\mathrm{mg} \mathrm{kg}^{-1}$ soil } & \multicolumn{2}{|c|}{ Centimeter below surface } \\
\hline & & p5 & p95 & p5 & p95 & $\mathrm{p} 5$ & p95 \\
\hline \multirow[t]{2}{*}{ Semi-natural grassland } & $\mathrm{T}$ & 5.2 & 7.4 & 0.6 & 8.0 & -3 & 63 \\
\hline & C & 4.3 & 6.8 & 1.2 & 38 & 13 & 98 \\
\hline \multirow[t]{2}{*}{ Heathland } & $\mathrm{T}$ & 3.8 & 5.5 & 0.0 & 1.0 & -21 & 48 \\
\hline & C & 2.8 & 5.4 & 0.2 & 34 & 5 & 108 \\
\hline \multirow[t]{2}{*}{ Forest } & $\mathrm{T}$ & 4.5 & 6.2 & 0.5 & 36 & 22 & 98 \\
\hline & C & 3.3 & 6.0 & 0.6 & 38 & 22 & 110 \\
\hline
\end{tabular}

\footnotetext{
${ }^{\mathrm{a}} T$ target, $C$ competing

${ }^{b}$ In the biodiversity indicator, the $\mathrm{pH}$ is expressed as $\mathrm{pH}-\mathrm{H}_{2} \mathrm{O}$ and the $\mathrm{NO}_{3}$ concentration as $\mathrm{NO}_{3}$ content in mg kg ${ }^{-1}$ soil. The $\mathrm{SMART}_{2}$ results on pH and $\mathrm{NO}_{3} \mathrm{I}^{-1}$ concentration in the soil solution were converted to $\mathrm{pH}-\mathrm{H}_{2} \mathrm{O}$ and $\mathrm{NO}_{3}$ content in $\mathrm{mg} \mathrm{NO} \mathrm{Ng}_{3} \mathrm{~kg}^{-1}$ soil (see text)
} 
National soil and vegetation maps were generalised and scaled to a $250 \times 250 \mathrm{~m}$ grid. Hydrological data, i.e. mean spring water level and upward water seepage fluxes, were derived from the national groundwater model (LGM, Pastoors 1993), with a resolution of $250 \times$ $250 \mathrm{~m}$. Deposition data were based on calculations for the past, based on emission inventories, deposition modelling and monitoring, and predictions for the future, performed by RIVM at a $5 \times 5 \mathrm{~km}$ grid (see "Deposition and hydrology scenarios" section).

\section{Spatial distribution of soil vegetation combinations}

We considered seven soil types, which were derived from the 1:50,000 soil map of the Netherlands (De Vries et al. 2003), i.e. poor sandy soils (SP), rich sandy soil (SR), calcareous sandy soils (SC), non-calcareous clay soils $(\mathrm{CN})$, calcareous clay soils (CC), peat soils (PN) and loess soils (LN). Soil-type classification was based on soil chemical criteria: parent material, presence of calcite, base saturation and texture (Additional file 1: Table S4).

We attributed the vegetation structures to five classes of vegetation structure types (Additional file 1: Table S5), i.e. deciduous forest (DEC), pine forest (PIN), spruce forest (SPR), heathland (HEA) and semi-natural grassland (GRP), based on difference in canopy characteristics, litter production, growth and vegetation management. The derivation of the areal distribution of the vegetation structure types over the soil types is described in the Additional file 1 and the results of the distributions are given in Additional file 1: Table S6.

\section{Data related to vegetation structure type and soil types}

In the model we distinguish data related to vegetation structure type (Additional file 1: Table S7), soil type (Additional file 1: Table S8) and soil-type vegetation structure-type combinations (Additional file 1: Table S9). These data were based on both literature data and monitoring data that are extensively described in the Additional file 1.

\section{Validation data}

To gain insight into the reliability of the SMART2 model predictions, we compared the modelled soil solution chemistry for forest with soil solution measurements in forest soils. Validation data were based on measured soil solution concentrations from 250 forested stands throughout the Netherlands as mentioned above. Where for acid sandy soils, measurements from 150 forest stands were used, sampled once during the period March to May in 1990 (De Vries et al. 1995). For clay, loess and peat soils, measurements from 100 forest stands were used, which were sampled once during the period March to May in 1994 (Klap et al. 1999).

It is important to realise that there exists some crucial differences between the modelled and observed samples (see also De Vries et al. 1994): (i) the number of the observed soil vegetation combinations differed from those that were simulated, (ii) the soil depth of the observations was always $60-100 \mathrm{~cm}$, whereas the soil depth used for the simulations varied from 50 to $100 \mathrm{~cm}$, depending on the soil/forest-type combination and (iii) SMART2 simulated flux weighted annual mean concentrations for the year 1990, whereas the field data were single observations in early spring either collected in 1990 or in 1994.

\section{Deposition and hydrology scenarios}

The temporal trends of chemical soil parameters predicted by SMART2 are driven by scenarios for atmospheric deposition and hydrology, which were based on a historical reconstruction for the past period 1990-2010, and projections for the period 2010-2030. Trends in atmospheric deposition fluxes of $\mathrm{NH}_{\mathrm{x}}, \mathrm{NO}_{\mathrm{x}}$ and $\mathrm{SO}_{\mathrm{x}}$ were based on observed trends for the past and constructed scenarios for the future (Table 3), while the deposition of base cations and $\mathrm{Cl}$ was kept constant during the simulation period (1980-2030). The hydrology scenarios were related to the changes in the MSW. The historical reconstruction was based

Table 3 National mean deposition used for $\mathrm{NH}_{x}, \mathrm{NO}_{x}$ and $\mathrm{SO}_{x}$ deposition for 1980, 1990 and 2010 and the Business as Usual (BU) and Improved Environment (IE) scenario in 2030

\begin{tabular}{llll}
\hline Year & \multicolumn{2}{l}{ Mean deposition } \\
\cline { 2 - 4 } & $\left(\mathrm{mol}_{\mathrm{c}} \mathrm{ha}^{-1} \mathrm{a}^{-1}\right)$ & & $\mathrm{NO}_{\mathrm{x}}$ \\
\cline { 2 - 4 } & $\mathrm{NH}_{3}$ & 876 & 1548 \\
1980 & 1887 & 854 & 799 \\
2000 & 1877 & 642 & 436 \\
2010 & 1242 & 535 & 384 \\
$2030(\mathrm{BU})$ & 1037 & 535 & 384 \\
2030 (IE) & 1037 & 388 & 320 \\
\hline
\end{tabular}

${ }^{\mathrm{a}}$ Deposition values refer to the beginning year of the period 
on current long-term mean fluxes and water levels. The solute concentrations in the upward seepage water were kept constant during the simulation period. For the projections, a Business as Usual (BU) and an Improved Environment (IE) scenario were used, both for the atmospheric deposition and hydrology for the period 2010-2030, which were evaluated for all combinations (Table 4). All simulations started in 1980, where the period 1980-1990 was used as initialisation period. The derivation of the $\mathrm{N}$ and $\mathrm{S}$ deposition scenarios, the base cation deposition, precipitation, upward seepage and MSW scenarios are given in Additional file 1. The geographical distribution in 1990 and the difference 2030-1990 for the $I E$ scenario for $\mathrm{N}$ and $\mathrm{S}$ deposition are given in Fig. 3. The national mean MSW values per vegetation structure type, soil type for several key years and the geographical distribution of the MSW in 1990 and the difference 2030-1990 for the IE scenario are given in Additional file 1: Table S10, Table S11 and Figure S2.

\section{Results}

We present a national scale validation of SMART2 outputs, and results of the scenario analysis of both SMART2 results on $\mathrm{pH}$ and $\mathrm{NO}_{3}$ concentration and the related results of the plant diversity indicator.

\section{Validation of SMART2 on soil solution chemistry}

A comparison of modelled soil solution $\mathrm{pH}, \mathrm{NH}_{4}$ and $\mathrm{NO}_{3}$ concentrations for forests (PIN, SPR, DEC) with soil solution measurements at $60-100-\mathrm{cm}$ depth for the various soil types are presented by comparing their median values (Table 5) as well as by box plots indicating the spread (Fig. 4). Additional validation results on $\mathrm{Al}$ concentrations are given in Additional file 1: Table S13.

The agreement between the observed and simulated median $\mathrm{pH}$ was generally good for sandy soils, but the model tended to underestimate the $\mathrm{pH}$ for loess and clay soils. Alternatively, the agreement for $\mathrm{NH}_{4}$ and $\mathrm{NO}_{3}$ was relatively poor (deviations larger than $50 \%$ ). $\mathrm{NH}_{4}$ concentrations were strongly underestimated in peat soils and to a lesser extent for sandy soils while $\mathrm{NH}_{4}$ concentrations were overestimated for clay soils. Only for loess

Table 4 Considered scenarios with respect to deposition and hydrology

\begin{tabular}{lll}
\hline Hydrology $^{\text {a }}$ & Deposition $^{\text {b }}$ & \\
\cline { 2 - 3 } & $\begin{array}{l}\text { Business as Usual } \\
(\mathrm{BU})\end{array}$ & $\begin{array}{l}\text { Improved Environment } \\
(\mathrm{IE})\end{array}$ \\
\hline Business as Usual (BU) & $\mathrm{BB}$ & $\mathbb{B}$ \\
Improved Hydrology & $\mathrm{Bl}$ & $\|$ \\
(IE) & &
\end{tabular}

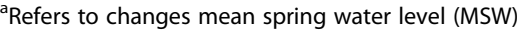

${ }^{\mathrm{b}}$ Refers to atmospheric deposition of $\mathrm{SO}_{x}, \mathrm{NO}_{\mathrm{x}}$ and $\mathrm{NH}_{3}$ soils, the $\mathrm{NH}_{4}$ concentrations corresponded rather well. Except for loess soils, median $\mathrm{NO}_{3}$ concentrations were overestimated, especially in poor sandy soils and clay soils. Only in rich sandy soils, the comparability was good.

Furthermore, the spread of the observed soil solution concentrations was much larger than the spread in modelled concentrations (Fig. 4), especially for the $\mathrm{pH}$ and the $\mathrm{NH}_{4}$ concentration.

\section{Scenario analysis with the combined SMART2-plant diversity indicator model Impacts of deposition and hydrology scenarios on abiotic site factors}

Effects of vegetation structure types and soil types on median $\mathrm{pH}$, nitrate concentration and their changes in time Changes in median soil $\mathrm{pH}$ and $\mathrm{NO}_{3}$ concentration in response to the various scenarios under different vegetation structure types are summarised in Table 6 . Vegetation structure types influence the soil chemistry by differences in nutrient cycle, filtering of dry deposition and transpiration. We started this section with the results of the II scenario (improved environment and improved hydrology) results for 1990 and 2010. A comparison of the results of the different scenarios for 2030 is discussed at the end of this section.

Reduced atmospheric deposition and increased groundwater level caused an increase in soil $\mathrm{pH}$ and a decrease in $\mathrm{NO}_{3}$ concentration. The $\mathrm{pH}$ increased by $0.1-0.2$ unit between 1990 and 2030 in response to the II scenario. The differences in the median between the vegetation structure types in 1990 were small $( \pm 0.1 \mathrm{pH})$. Grassland soils and deciduous forest showed the largest $\mathrm{pH}$ values throughout the simulation period. This is partly because a relatively large part of grassland and deciduous forest is located on calcareous sandy soils or clay soils (see Additional file 1: Table S6) and on soils with a higher groundwater level (i.e. wetter circumstances). The differences in median $\mathrm{NO}_{3}$ concentration between the vegetation structure types in 1990 were larger than the differences in $\mathrm{pH}$, which is mainly due to differences in filtering of dry deposition and transpiration. The highest $\mathrm{NO}_{3}$ concentrations were found for spruce, having the highest filtering of dry deposition and transpiration.

The most notable changes were found for $\mathrm{NO}_{3}$ concentration. For all vegetation structure types, the median $\mathrm{NO}_{3}$ concentration was lower in $2010(-38 \%)$ and 2030 (II) $(-45 \%)$ than in 1990. Between 1990 and 2030, the strongest decrease in $\mathrm{NO}_{3}$ concentration was found for forests, ranging from $44 \%$ (for pine forest) to $48 \%$ (for deciduous forest). For heathland, the decrease was slightly lower, 42\%, whereas the lowest decrease was found for grassland, 24\%. For $\mathrm{pH}$, the changes were 


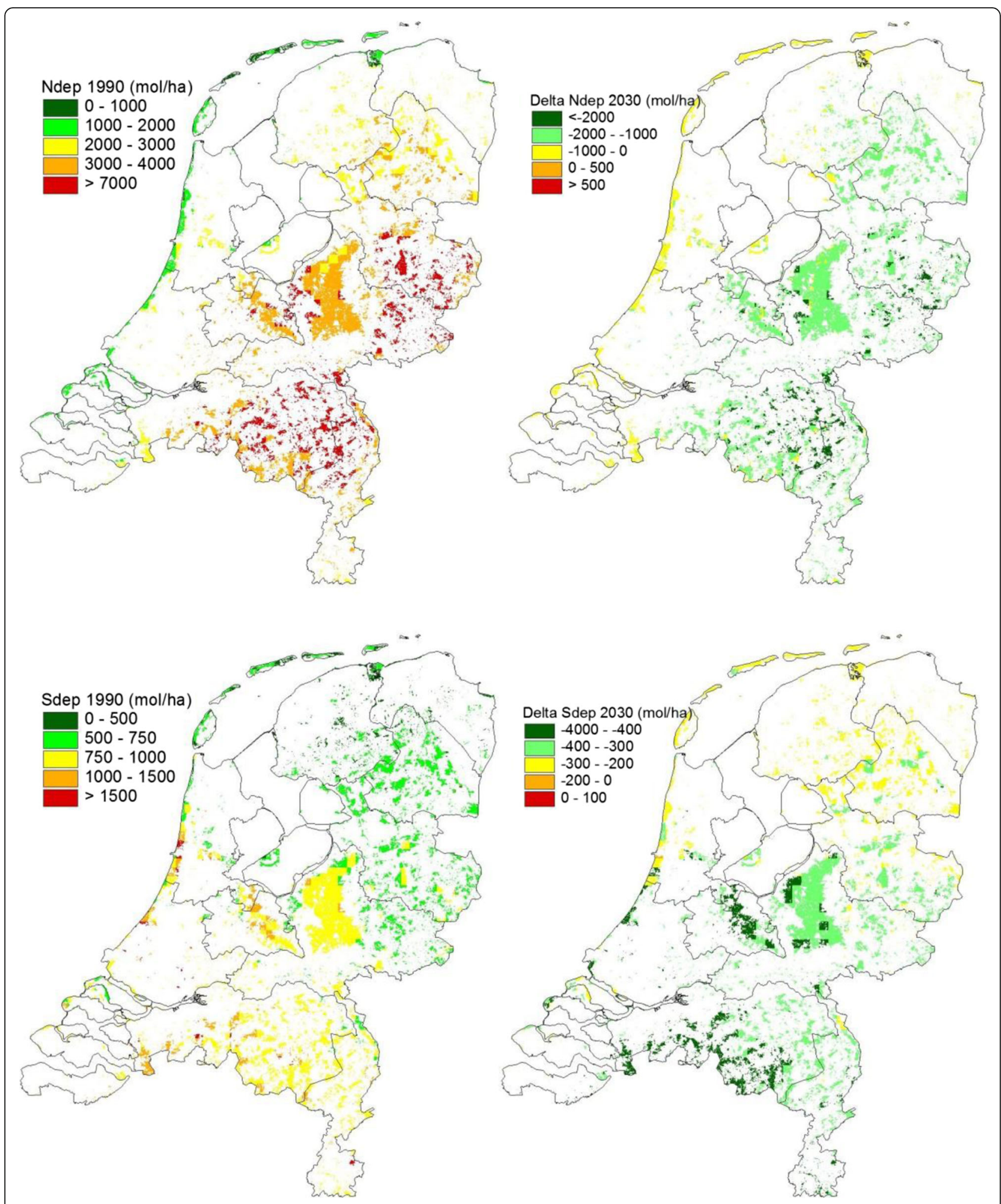

Fig. 3 Geographical distribution of the $\mathrm{NO}_{x}+\mathrm{NH}_{3}$ deposition (in $\mathrm{mol}_{\mathcal{C}}$ ha $^{-1}$ year ${ }^{-1}$; top) and $\mathrm{SO}_{x}$ deposition (in mol ha $^{-1}$ year ${ }^{-1}$; bottom) in 1990 (left) and the difference 2030-1990 for the IE deposition scenario (in mol $\mathrm{Cha}^{-1}$ year $^{-1}$; right) 
smaller. The highest changes (increase) was found for grassland $(0.21 \mathrm{pH}$ increase in 2030 (II) compared to 1990). For forest, the median $\mathrm{pH}$ increased with 0.08 unit whereas the lowest increase was found for heathland $(0.03 \mathrm{pH}$ unit).

Soil type influences the soil chemistry by differences in weathering rates and cation exchange capacity. The effect of soil type was much more pronounced than the effect of vegetation. Of course, a clear distinction exists between calcareous and non-calcareous soils. Calcareous soils have a high $\mathrm{pH}$ due to the presence of calcite. There was no effect of the combined scenario on the $\mathrm{pH}$ of calcareous soils. Due to the carbonate equilibrium, this was kept at a $\mathrm{pH}$ near 6.7, irrespective of deposition level and seepage input. The non-calcareous clay soils also had a rather high $\mathrm{pH}$, near 5.7, due to high weathering rates. All other non-calcareous soils, i.e. sand, loess and peat soils, had a pH near 4, indicating that these soil are strongly acidified, with poor sandy soils and peat soils being most acid. Deposition reductions and increase in groundwater level caused an increase in $\mathrm{pH}$ for all soil types.

The lowest $\mathrm{NO}_{3}$ concentrations were found in calcareous soils and in peat soils. The low $\mathrm{NO}_{3}$ concentrations in calcareous soils were related to relatively low atmospheric inputs of $\mathrm{N}$, since they are mainly generally located along the coast line in the western part of the country (see Fig. 6) with relatively low $\mathrm{N}$ deposition (see Fig. 3). The low $\mathrm{NO}_{3}$ concentrations in calcareous soils were due to high denitrification rates, caused by wet circumstances. The highest $\mathrm{NO}_{3}$ concentrations were found in poor sandy soils $\left(0.82 \mathrm{~mol}_{\mathrm{c}} \mathrm{m}^{-3}\right.$ in 1990), being related to a combination of relatively low denitrification rates (generally dry soils) and high atmospheric inputs of $\mathrm{N}$, as they are generally located in areas with high intensive animal husbandry with high ammonia emissions (Kros et al. 2004).

The impact of deposition reductions alone, i.e. 13\% reduction in total $\mathrm{N}$ deposition, $\mathrm{NH}_{3}+\mathrm{NO}_{\mathrm{x}}$ (see Table 3), had hardly any effect on the median $\mathrm{pH}$ and only a slight effect on the $\mathrm{NO}_{3}$ concentration in 2030 (compare $I B$ with $B B$ in Tables 6 and 7). The median $\mathrm{NO}_{3}$ concentration for all sites decreased by $11 \%$ (from 0.47 to $0.42 \mathrm{~mol}_{\mathrm{c}} \mathrm{m}^{-3}$ ) with the highest decrease for heathland $(15 \%)$ and the lowest for spruce forest (6\%) (Table 7). Per soil type, the highest reductions were found for loess soils (30\%) followed by sandy soils (about $10 \%$ ). The very limited changes in abiotic factors are due to the low deposition reductions for the $I E$ scenario in 2030 (especially compared to the changes in the period 2000-2010, see Table 3).

An increase in groundwater level (compare $B I$ with $B B$ in Tables 6 and 7) did not result in a change in mean $\mathrm{pH}$ in forests but caused a slight change in grasslands. The effect on the mean $\mathrm{NO}_{3}$ concentration was larger, a reduction from $0.47 \mathrm{~mol}_{\mathrm{c}} \mathrm{m}^{-3}(B B)$ to $0.42 \mathrm{~mol}_{\mathrm{c}} \mathrm{m}^{-3}(B I)$ (11\%). Per vegetation structure type (Table 6 ), the highest additional decreases in mean $\mathrm{NO}_{3}$ concentrations, due to increase groundwater level $(B I)$ on top of deposition reductions $(I B)$, were found for grassland (22\%), deciduous (15\%) and spruce (8\%). Per soil type (Table 7), the highest reductions in mean $\mathrm{NO}_{3}$ concentrations were found for peat soils (38\%) followed by calcareous soils (both sand, 20\%, and clay, 27\%). Reductions for non-calcareous sandy and clay soils were clearly lower. This was due relatively high denitrification rates (see Additional file 1 Eq. (63)), for peat soil (due to wet circumstances) and calcareous soils (due to high $\mathrm{pH}$, see Additional file 1 Eq. (64)), resulting in a stronger increase in denitrification at increasing groundwater levels than for mineral soils (lower groundwater levels) and non-calcareous soils (lower $\mathrm{pH})$, respectively.

Geographical distribution of $\mathrm{pH}$ and nitrate concentration Maps with the median $\mathrm{pH}$ and $\mathrm{NO}_{3}$ concentration per $1 \times 1 \mathrm{~km}$ cell for all vegetation structure types in the year 1990 and 2030 for the II scenario are presented in Figs. 5 and 6. The spatial distribution in $\mathrm{pH}$ reflects the distribution in soil types. Calcareous sandy soils and clay soils along the coast line and clay soils along the rivers are well buffered at relatively high $\mathrm{pH}$ values. Non-calcareous sandy soils

Table 5 Median values of soil solution $\mathrm{pH}_{1} \mathrm{NH}_{4}$ and $\mathrm{NO}_{3}$ concentration as observed at 60-100-cm depth (Obs.) and predicted for 1990 (Mod.) by SMART2 for forests (PIN, SPR, DEC)

\begin{tabular}{|c|c|c|c|c|c|c|c|c|}
\hline \multirow[t]{2}{*}{ Soil type } & \multicolumn{2}{|l|}{$N^{a}$} & \multicolumn{2}{|l|}{$\mathrm{pH}$} & \multicolumn{2}{|c|}{$\begin{array}{l}\mathrm{NH}_{4} \\
\left(\mathrm{~mol}_{\mathrm{C}} \mathrm{m}^{-3}\right)\end{array}$} & \multicolumn{2}{|c|}{$\begin{array}{l}\mathrm{NO}_{3} \\
\left(\mathrm{~mol}_{\mathrm{C}} \mathrm{m}^{-3}\right) \\
\end{array}$} \\
\hline & Obs. & Mod. & Obs. & Mod. & Obs. & Mod. & Obs. & Mod. \\
\hline Sand poor & 27 & 43226 & 4.0 & 3.8 & 0.08 & 0.01 & 0.25 & 0.85 \\
\hline Sand rich & 28 & 10000 & 3.8 & 3.8 & 0.08 & 0.00 & 0.33 & 0.38 \\
\hline Peat & 30 & 7724 & 3.8 & 3.8 & 0.24 & 0.02 & 0.02 & 0.07 \\
\hline Loess & 40 & 826 & 4.3 & 3.8 & 0.04 & 0.01 & 0.72 & 0.50 \\
\hline Clay & 13 & 3428 & 6.3 & 5.8 & 0.00 & 0.07 & 0.11 & 0.47 \\
\hline
\end{tabular}

${ }^{\mathrm{a}} \mathrm{N}$ represents the number observed and simulated soil vegetation combinations 


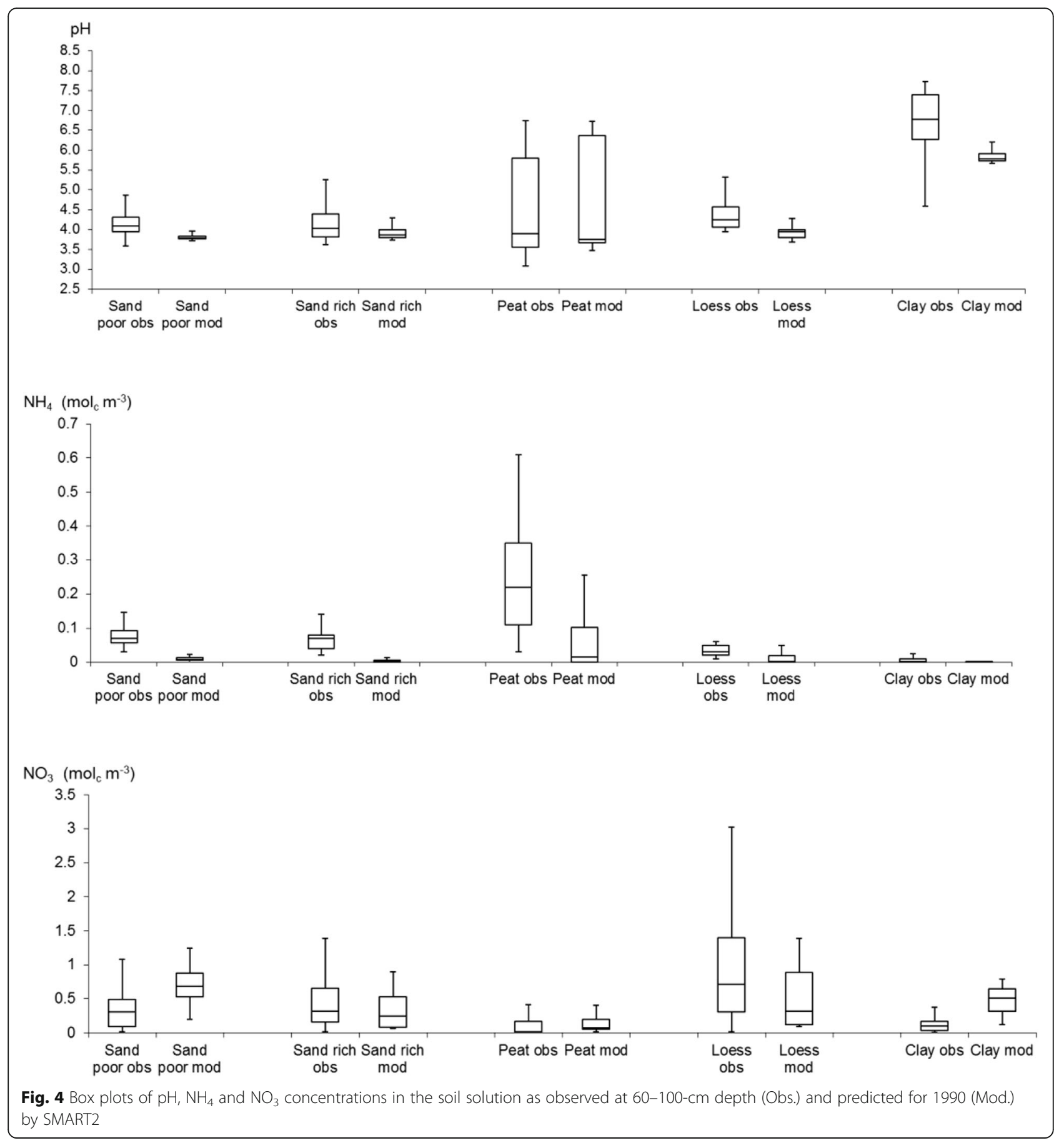

in the central and southern part of the country have a lower buffer capacity, resulting in a lower pH. Deposition reductions and increased groundwater levels resulted in an increase in $\mathrm{pH}$ values, especially for the soils with a relatively low $\mathrm{pH}(<4)$. These locations generally correspond with the poor sandy soils (Fig. 5).
The spatial distribution in $\mathrm{NO}_{3}$ concentration reflects the distribution in vegetation structure type and $\mathrm{N}$ deposition. High concentrations were predicted in the central and southern part of the country, with a relatively large share of spruce forest and high $\mathrm{N}$ deposition (see Fig. 3), and low concentrations were predicted in the northern part of the country, 
Table 6 Predicted median $\mathrm{pH}$ and $\mathrm{NO}_{3}$ concentration in the root zone for the distinguished vegetation structure types on all soil types in 1990, 2010 and 2030 in response to combined deposition and hydrology scenarios

\begin{tabular}{|c|c|c|c|c|c|c|}
\hline \multirow[t]{2}{*}{ Vegetation } & \multirow[t]{2}{*}{1990} & \multirow[t]{2}{*}{2010} & \multicolumn{4}{|c|}{$2030^{a}$} \\
\hline & & & 11 & $B B$ & IB & $B l$ \\
\hline & \multicolumn{6}{|l|}{$\mathrm{pH}$} \\
\hline Spruce & 3.93 & 4.03 & 4.01 & 4.02 & 4.01 & 4.02 \\
\hline Pine & 3.98 & 4.08 & 4.06 & 4.06 & 4.06 & 4.07 \\
\hline Deciduous & 4.07 & 4.19 & 4.17 & 4.18 & 4.17 & 4.19 \\
\hline Heather & 3.82 & 3.88 & 3.85 & 3.85 & 3.85 & 3.85 \\
\hline Grass & 4.09 & 4.30 & 4.30 & 4.40 & 4.39 & 4.32 \\
\hline \multirow[t]{2}{*}{ All } & 3.99 & 4.09 & 4.07 & 4.08 & 4.07 & 4.08 \\
\hline & \multicolumn{6}{|c|}{$\mathrm{NO}_{3}$ concentration $\left(\mathrm{mol}_{\mathrm{c}} \mathrm{m}^{-3}\right)$} \\
\hline Spruce & 1.42 & 0.77 & 0.78 & 0.91 & 0.85 & 0.82 \\
\hline Pine & 0.95 & 0.52 & 0.53 & 0.63 & 0.55 & 0.59 \\
\hline Deciduous & 0.50 & 0.28 & 0.26 & 0.34 & 0.31 & 0.29 \\
\hline Heather & 0.66 & 0.43 & 0.38 & 0.47 & 0.40 & 0.45 \\
\hline Grass & 0.21 & 0.17 & 0.16 & 0.23 & 0.21 & 0.18 \\
\hline All & 0.66 & 0.41 & 0.36 & 0.47 & 0.42 & 0.42 \\
\hline
\end{tabular}

${ }^{a}$ The first character refers to the deposition scenario and the second character refers to the hydrology scenario, e.g. IB refers to IE deposition scenario and to the $B U$ hydrology scenario

Table 7 Predicted median $\mathrm{pH}$ and $\mathrm{NO}_{3}$ concentration in the root zone for the distinguished vegetation structure types on all soil types in 1990, 2010 and 2030 in response to combined deposition and hydrology scenarios

\begin{tabular}{|c|c|c|c|c|c|c|}
\hline \multirow[t]{2}{*}{ Soil type } & \multirow[t]{2}{*}{1990} & \multirow[t]{2}{*}{2010} & \multicolumn{4}{|c|}{$2030^{\mathrm{a}}$} \\
\hline & & & 11 & $B B$ & IB & $B l$ \\
\hline & \multicolumn{6}{|l|}{$\mathrm{pH}$} \\
\hline Sand poor & 3.98 & 4.07 & 4.05 & 4.05 & 4.05 & 4.06 \\
\hline Sand rich & 4.01 & 4.12 & 4.10 & 4.11 & 4.10 & 4.11 \\
\hline Sand calc. & 6.93 & 6.94 & 6.94 & 6.94 & 6.94 & 6.95 \\
\hline Clay & 5.70 & 5.78 & 5.77 & 5.77 & 5.76 & 5.77 \\
\hline Clay calc. & 6.73 & 6.74 & 6.74 & 6.74 & 6.74 & 6.74 \\
\hline Loess & 4.07 & 4.17 & 4.16 & 4.12 & 4.13 & 4.16 \\
\hline Peat & 3.74 & 3.86 & 3.85 & 3.86 & 3.85 & 3.86 \\
\hline \multirow[t]{2}{*}{ All } & 3.99 & 4.09 & 4.07 & 4.08 & 4.07 & 4.08 \\
\hline & \multicolumn{6}{|c|}{$\mathrm{NO}_{3}$ concentration $\left(\mathrm{mol}_{\mathrm{C}} \mathrm{m}^{-3}\right)$} \\
\hline Sand poor & 0.82 & 0.48 & 0.47 & 0.56 & 0.5 & 0.53 \\
\hline Sand rich & 0.50 & 0.32 & 0.33 & 0.41 & 0.36 & 0.37 \\
\hline Sand calc. & 0.12 & 0.13 & 0.14 & 0.20 & 0.19 & 0.16 \\
\hline Clay & 0.43 & 0.29 & 0.25 & 0.31 & 0.29 & 0.27 \\
\hline Clay calc. & 0.14 & 0.11 & 0.09 & 0.15 & 0.14 & 0.11 \\
\hline Loess & 0.54 & 0.38 & 0.31 & 0.47 & 0.33 & 0.40 \\
\hline Peat & 0.06 & 0.05 & 0.04 & 0.08 & 0.07 & 0.05 \\
\hline All & 0.66 & 0.41 & 0.36 & 0.47 & 0.42 & 0.42 \\
\hline
\end{tabular}

${ }^{a}$ The first character refers to the deposition scenario and the second character refers to the hydrology scenario, e.g. IB refers to IE deposition scenario and to the BU hydrology scenario 


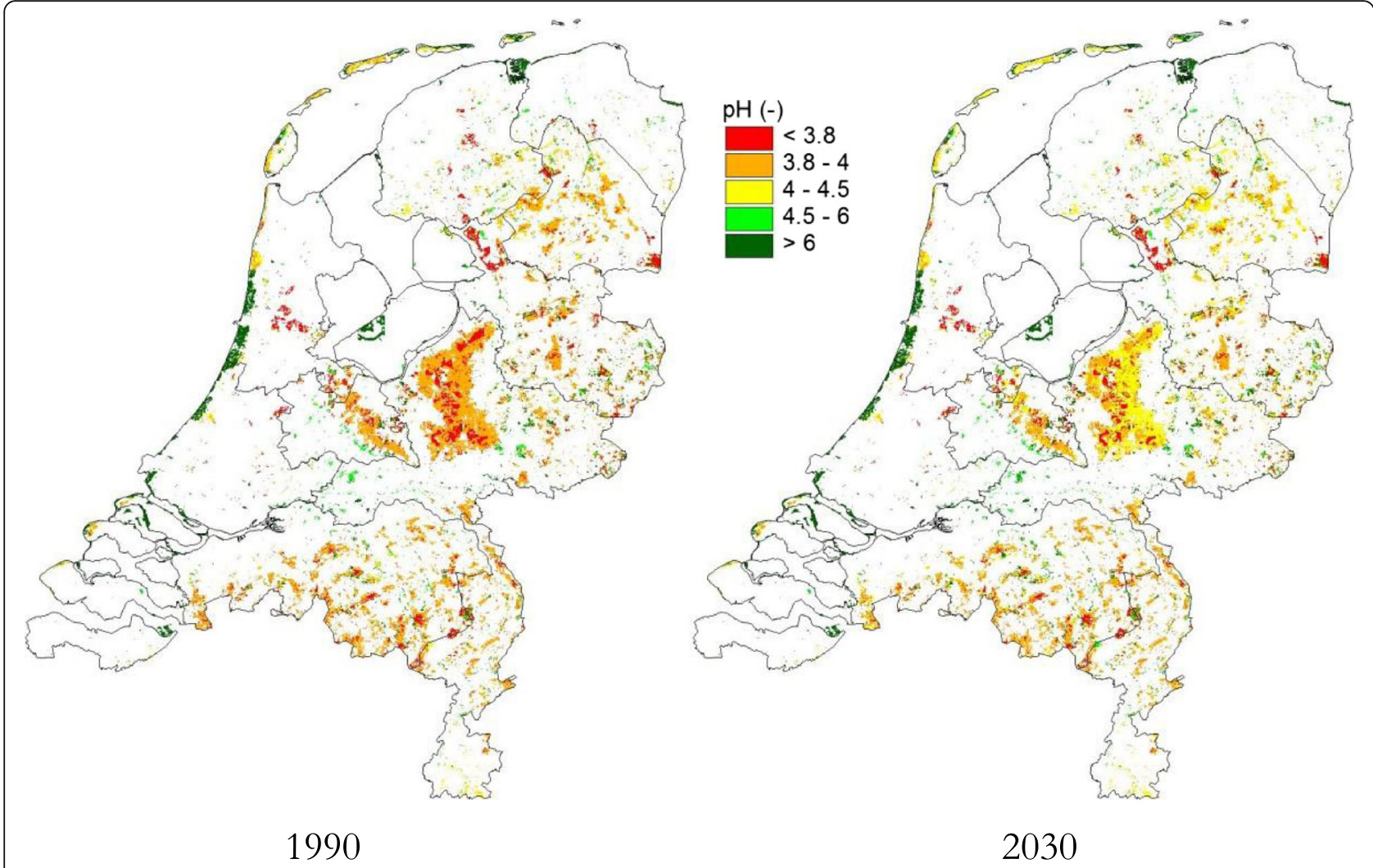

Fig. 5 Geographical distribution of the pH in the root zone of the dominant semi-natural terrestrial ecosystems in a $250 \times 250 \mathrm{~m}$ grid cell in 1990 (left) and 2030 (right), for the II scenario

especially for grasslands along the coast line, with relatively low $\mathrm{N}$ deposition (Fig. 6). Due to the $I I$ scenario, the $\mathrm{NO}_{3}$ concentration clearly decreased in 2030 compared to 1990.

\section{Impacts of deposition and hydrology scenarios on plant species}

The effects of calculated changes in $\mathrm{pH}, \mathrm{NO}_{3}^{-}$concentration and MSW in response to the four scenarios on the percentage target and competing species in grassland, heathland and deciduous forest ecosystem are shown in Table 8 . For all vegetation structure types, the $B B$ scenario resulted in a strongly significant $(p<0.01)$ increase in the mean percentage of target species and in seminatural grasslands in a very strongly significant $(p<$ 0.001 ) decrease in the mean percentage of competing species, thus implying a very strongly significant increase $(p<0.001)$ in the plant diversity indicator (the ratio target species to competing species). Note that in the $B B$ scenario, the results for 2030 are comparable with 2010 (no changes in that period) and the improvements are thus due to deposition reduction and groundwater changes between 1990 and 2010. Compared to the $B B$ scenario, the $I B 2030$ scenario, i.e. the deposition effect, did not lead to a significant effect on either target species or competing species except for heathland showing a significant $(p<0.05)$ increase in competing species (Table 8). Compared to the $B B$ scenario, the $B I$ scenario, i.e. the hydrology effect, showed a very strongly significant $(p<0.001)$ increase in target species for all considered vegetation structure types. For heathland and deciduous forest, this coincided with a very strong significant increase in competing species. The increase in target species due to the hydrology scenario $B I$ as compared to $B B$ was largest for heathland (from 0.78 to $1.14 \%$ ), followed by deciduous forest (from 3.0 to $3.53 \%$ ) and grassland (4.14 to $4.27 \%$ ).

The increase in competing species, that coincide with increasing target species, was highest for heathland (12 to $16 \%$ ) and being larger than the increase in target species (from 0.8 to $1.2 \%$ ). This might be an indication that plant diversity in heathland cannot be restored without additional restoration measures, such as grazing or sod cutting. However, the ratio target to competing species showed a very strongly significant $(p<0.001)$ increase (from 0.07 to 0.12 ), indicating a relative increase of target species. For deciduous forest, the increase in competing species (from 19 to $20 \%$ ) was comparable to the increase in target species (from 3.0 to 3.6\%), leaving the 


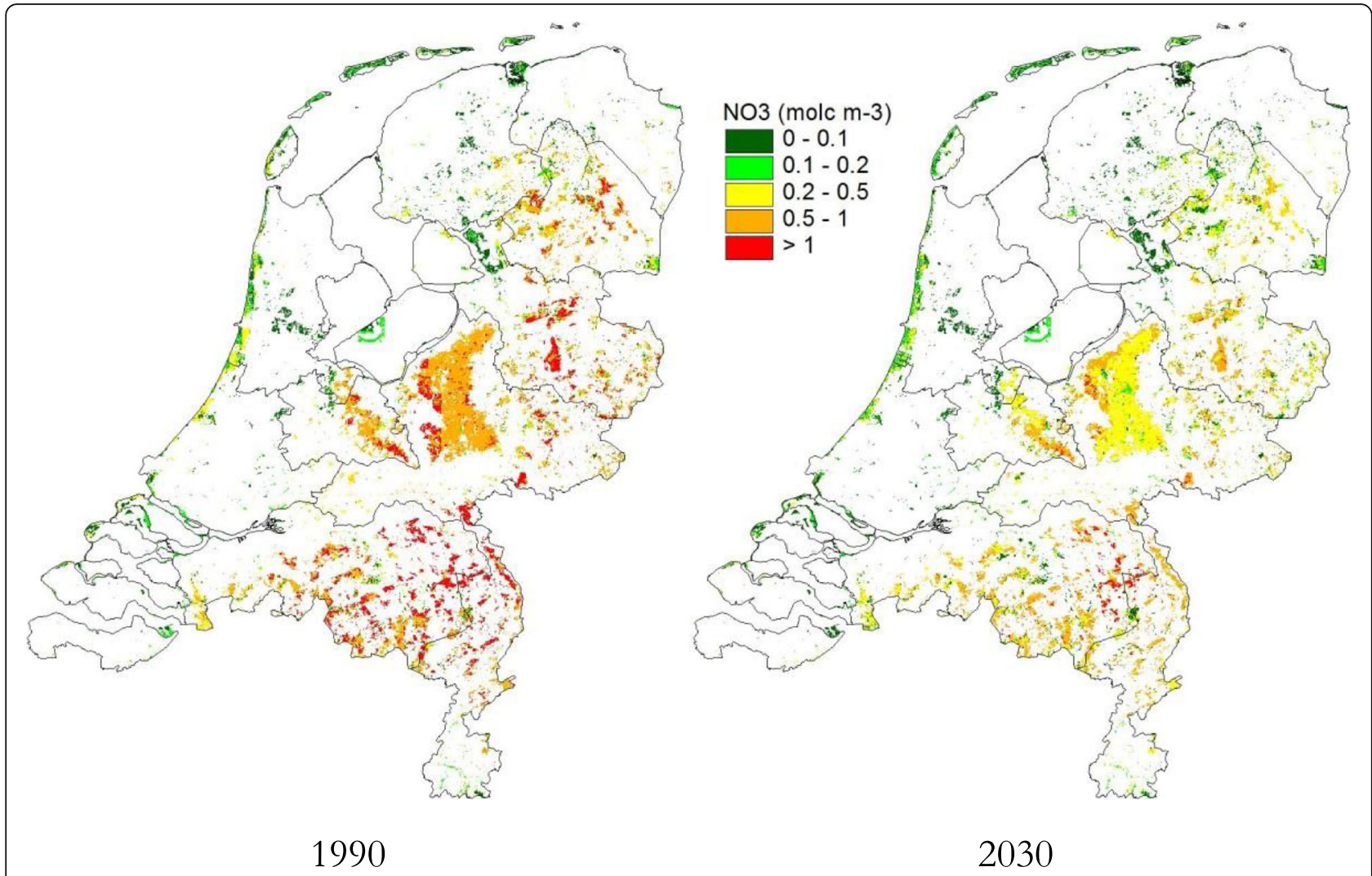

Fig. 6 Geographical distribution of the $\mathrm{NO}_{3}$ concentration $\left(\mathrm{mol}_{c} \mathrm{~m}^{-3}\right)$ in the root zone of the dominant semi-natural terrestrial ecosystems in a $250 \times 250 \mathrm{~m}$ grid cell in 1990 (left) and 2030 (right), for the II scenario

ratio target to competing species nearly unchanged for the $B I$ scenario (no significant difference).

Figure 7 shows that the largest areas with increase in target species occurred mainly in northwestern parts of the country, areas mainly covered by grassland (Fig. 7, left). For large part of these areas, this coincided with a decrease in competing species, indicating an improvement of target and red list plant species. The areas with an increase in competing species were mainly located in the northeastern part of the country and fragmented spots in the central and southeastern part of the country, which are mainly related to heathland, and occurring in a relatively large amount in this area. When focusing on the combined effect (Fig. 7, bottom), it appeared that at most locations with increasing target species, the ratio target species to competing species was increasing.

\section{Discussion}

\section{Validation}

Our validation is limited to soil solution concentrations under forest on non-calcareous soils. For other vegetation structure types, additional data gathering on soil and soil solution would be required. Furthermore, the validation is partly biased because the same data set was used for the derivation of parts of the model parameters, e.g. soil solution concentrations were used for the derivation of cation exchange constants.

Validation on soil solution chemistry below forests yielded satisfactory results for $\mathrm{pH}$, but the model tends to overestimate the $\mathrm{NO}_{3}$ contractions in poor sandy soils and clay soils. Given the underestimation of $\mathrm{NH}_{4}$ concentrations and the slight overestimation of the $\mathrm{NO}_{3}$ concentrations in peat soils, $\mathrm{N}$ mineralisation might be underestimated or denitrification overestimated for peat soils. The overestimation of the $\mathrm{NO}_{3}$ concentrations for sandy soils and clay soils might be due to an overestimation of mineralisation or an underestimation of denitrification. Especially, the overestimation of mineralisation in poor sandy soil requires attention, because these soils cover a large part of the forests in the Netherlands and vulnerable groundwater reservoirs. Moreover, the relatively small spread in modelled concentrations, especially for $\mathrm{pH}$ and $\mathrm{NH}_{4}$, indicates that the use of generic model parameters per soil type and/or vegetation structure types is over-simplified and more diversity in parameterisation of various soil types and/or vegetation structure types is needed. However, when aggregating the SMART2 results to a larger grid size, e.g. $5 \times 5 \mathrm{~km}$, the extent of overestimation is reduced significantly, as was shown by Kros et al. (2004). Nevertheless, these deviations indicate that the 
Table 8 Calculated mean percentage (\%) and standard deviations (SD) of occurrence of target species, competing species and the ratio target species to competing species for semi-natural grassland, heathland and deciduous forests for the four scenarios in 2030 compared to 1990, the $p$ value, indicating the significance level for the difference from the reference scenario (BB-2030)

\begin{tabular}{|c|c|c|c|c|c|c|c|c|}
\hline \multirow[t]{2}{*}{ Scenario } & \multicolumn{3}{|c|}{ Target species } & \multicolumn{3}{|c|}{ Competing species } & \multicolumn{2}{|c|}{ Target/competing } \\
\hline & $\%$ & $S D^{a}$ & $p^{b}$ & $\%$ & SD & $p^{b}$ & - & $p^{b}$ \\
\hline & \multicolumn{8}{|c|}{ Semi-natural grassland } \\
\hline 1990 & 3.93 & 7.1 & $* *$ & 12.38 & 13.3 & $* * *$ & 0.542 & $* * *$ \\
\hline BB 2030 & 4.14 & 7.1 & - & 11.94 & 13.9 & - & 0.585 & - \\
\hline IB 2030 & 4.04 & 7.0 & - & 12.10 & 14.0 & - & 0.573 & - \\
\hline Bl 2030 & 4.27 & 7.0 & $*$ & 11.75 & 13.2 & - & 0.519 & $* * *$ \\
\hline \multirow[t]{2}{*}{ || 2030} & 4.18 & 6.9 & - & 11.68 & 13.3 & * & 0.504 & *** \\
\hline & \multicolumn{8}{|c|}{ Heathland } \\
\hline 1990 & 0.67 & 2.2 & $* *$ & 11.69 & 22.0 & - & 0.066 & - \\
\hline BB 2030 & 0.78 & 2.8 & - & 12.23 & 22.5 & - & 0.073 & - \\
\hline IB 2030 & 0.84 & 2.9 & - & 13.04 & 23.1 & * & 0.072 & - \\
\hline BI 2030 & 1.14 & 3.9 & $* * *$ & 15.33 & 25.5 & $* * *$ & 0.123 & *** \\
\hline \multirow[t]{2}{*}{ || 2030} & 1.23 & 3.9 & $* * *$ & 16.35 & 26.3 & $* * *$ & 0.120 & $* * *$ \\
\hline & \multicolumn{8}{|c|}{ Deciduous forest } \\
\hline 1990 & 2.58 & 4.9 & $* * *$ & 12.87 & 19.0 & - & 0.245 & $* * *$ \\
\hline BB 2030 & 3.00 & 5.5 & - & 12.22 & 19.1 & - & 0.323 & - \\
\hline IB 2030 & 3.04 & 5.4 & - & 12.31 & 19.2 & - & 0.324 & - \\
\hline Bl 2030 & 3.53 & 5.1 & $* * *$ & 14.45 & 20.1 & $* * *$ & 0.330 & - \\
\hline || 2030 & 3.59 & 5.2 & $* * *$ & 14.51 & 20.2 & $* * *$ & 0.338 & - \\
\hline
\end{tabular}

${ }^{\mathrm{a}}$ Standard deviation

${ }^{\mathrm{b}} p$ value, indicating the significance level for the difference from the BB scenario (2030):

- no difference $(0.10<p)$

$\sim$ indication for a difference $(0.05<p<0.10)$

*a significant difference $(0.01<p<0.05)$

**a strong significant difference $(0.001<p<0.01)$

***a very strong significant difference $(p<0.001)$

parameterisation of the nitrogen dynamics in SMART2 needs improvements.

In conclusion, the application of the SMART2 model to the whole of the Netherlands, while only parameterised on a small number of monitored sites, yields inadequate results for $\mathrm{NO}_{3}$, although $\mathrm{pH}$ predictions seem reasonable. As was shown in Kros et al. (2002), the performance of the SMART2 model could be improved strongly by model calibration at the appropriate spatial scale. Alternatively, a site-specific calibration at a national level could be considered, aiming at optimising spatially distributed model parameters (Reinds et al. 2008). Another approach to improve the (de)nitrification and mineralisation parameters is to use the validation data for a Bayesian calibration (see e.g. Reinds et al. 2008). However, one has to be aware that other factors which may contribute to the overestimation of the $\mathrm{NO}_{3}$ concentrations, such as the role of forest filtering. Forest filtering of a larger continuous area of dense forests is generally low (Draaijers and Erisman 1993). The SMART2 model, however, includes constant forest filtering factors that only depend on forest type, independent of the forested area, thus, overestimating the input of atmospheric deposition in relatively large forested areas (Kros et al. 2004).

\section{Plant diversity indicator}

It was shown that the percentage target species becomes higher over time when the mean spring groundwater level raises and the nitrogen deposition drops. This effect is visible for all vegetation types. The results of the $B B$ scenario, indicating the changes between 1990 and 2010 since MSW and N deposition is kept constant between 2010 and 2030, indicate that the drop in $\mathrm{N}$ deposition in that period has led to a significant increase in target species. However, for the period 2010, the expected change in MSW is the main cause for an expected significant increase in target species. This is most likely mainly due to the expected small deposition reduction in that period (from $1600 \mathrm{~mol} \mathrm{~N}$ in 2010 to $1400 \mathrm{~mol} \mathrm{~N}$ for the $I E$ scenario in 2030, see Table 3), and at these deposition levels, critical loads are still exceeded in relatively large parts of the Natura 2000 sites (PAS 2015). This result is in line with earlier results 


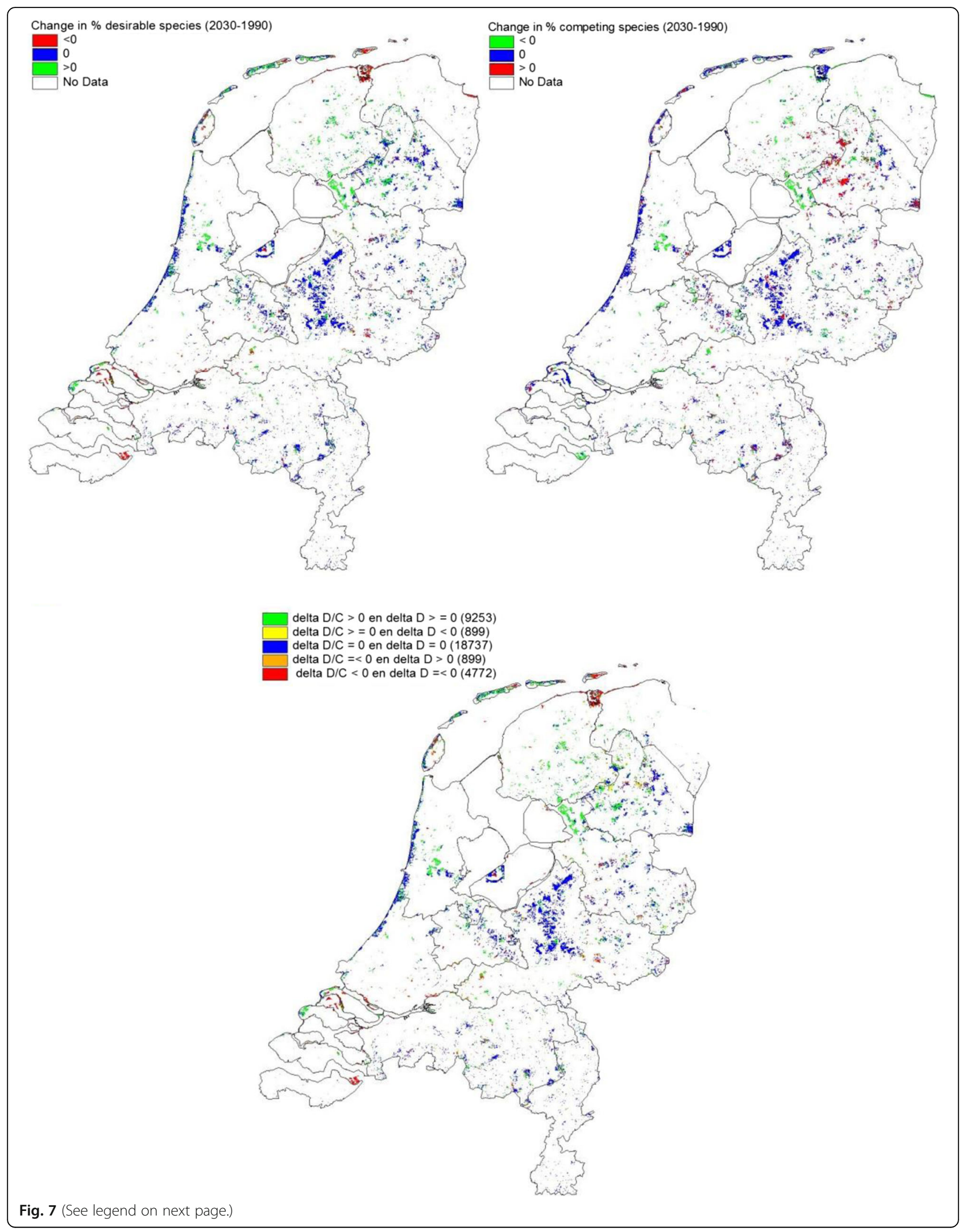


(See figure on previous page.)

Fig. 7 Predicted geographical distribution of the relative change in probability of occurrence of target (left) and competing (right) plant species typical for all considered ecosystems between 1990 and 2030 in response to the I/ scenario and the relative change in probability of occurrence in combination with the change in ratio in probability of occurrence of target (T) and competing species (C) (bottom). Values in brackets represent the number of grid cells within the corresponding class

where the effect of limited nitrogen deposition decrease was also small, with effects only being visible at drastic $\mathrm{N}$ deposition reductions (Van Dobben et al. 2002; Wamelink et al. 2003). It was then suggested that a drop in nitrogen deposition not automatically leads to a lower nitrogen availability in the soil and thus a higher plant diversity. Measures as removal of the excessive nitrogen in the system by vegetation management are then necessary, which is also supported by modelled increase in competing species.

An important aspect of the application of the plant diversity indicator is the transformation from calculated $\mathrm{NO}_{3}$ concentrations in soil solution, as calculated in SMART2, towards nitrogen content per kilogram of soil as used in the plant diversity indicator (see Additional file $1 \mathrm{Eq}$. (72)). For this transformation, a generic soil moisture content $(\mathrm{kg}$ water $/ \mathrm{kg}$ soil) and bulk density $\left(\mathrm{kg} \mathrm{m}^{-3}\right)$ was used. This approach introduces a relatively high uncertainty, since the actual soil moisture content during sampling, which was not measured, may deviate considerably from the used generic value. The used conversion from $\mathrm{pH}-\mathrm{H}_{2} \mathrm{O}$ to the $\mathrm{pH}$ in soil solution is less subject to uncertainty, since the used relations are rather robust $\left(R^{2}>0.8\right.$, Kros 1998).

The competing species give unexpected results; they also increase for the scenarios. This may be caused by inclusion of exotic species in the competing species list. Though this seems logical, this can cause unexpected results. Some of the exotic species, especially tree species, were planted on purpose, e.g. for wood production. Our plant diversity indicator was partly designed to indicate unfavourable nutrient-rich situations. However, especially the planted trees will also flourish under nutrientpoor circumstances, e.g. Pinus sylvestris or Larix kaempferi. This is reflected in their abiotic ranges which also include nutrient-poor circumstances. This results in the presence of competing species under a lower nitrogen deposition and partly explains the presence of competing species even under nutrient-poor circumstances, as was found here. Moreover, species that become dominant under nutrient (nitrogen)-rich circumstances, and here defined as competing, often can also occur under nutrient-poor circumstances without becoming dominant. But they still can occur and are as such predicted to be present. We conclude that the list of target species may give a good indication of the plant diversity to be expected, but that the list of competing species and the used criteria need further reviewing.
Furthermore, there is growing evidence that in nearly all situations, both in freshwater and terrestrial ecosystems, $\mathrm{N}$ is not the limiting factor but the limitation by phosphorus $(\mathrm{P})$ is as important and in most cases there is a synergistic effects of $\mathrm{N}$ and $\mathrm{P}$ enrichment (Elser et al. 2007; Wassen et al. 2005). Moreover, species-rich grassland can persist under nitrogen-rich but P-limited conditions (Van Dobben et al. 2016). This is a motivation for incorporating $\mathrm{P}$ in the plant diversity indicator. This, however, is not an easy task due to the nature of the availability of phosphorus and also due to the lack of suitable data. Finally, other site factors beyond $\mathrm{pH}$, nutrient availability and groundwater level, may influence species richness. It has been found that also microclimate (air temperature and air humidity) influences heath succession (Mantilla-Contreras et al. 2011). But these aspects are difficult to combine with a model that operates at a yearly time scale and a spatial resolution of $250 \times$ $250 \mathrm{~m}$.

\section{Uncertainties \\ Model structure}

The assessment of the uncertainty in SMART2 predictions due to input uncertainty and spatial variability in those data are addressed by Kros et al. (1999; 2002). We restrict ourselves to a qualitative discussion of the consequences of crucial assumptions made in this model application. Uncertainties caused by model structure are due to model assumptions and simplifications because of insufficient knowledge, to limit data requirements and for operational reasons (e.g. application at a scale that requires model simplification). The lack of knowledge with respect to acidification and nutrient cycling models mainly concerns the dynamics of organic matter, $\mathrm{N}$ and $\mathrm{Al}$ (De Vries 1994; Kros et al. 1993). Especially the uncertainties in $\mathrm{Al}$ and $\mathrm{N}$ dynamics may seriously contribute to the uncertainty in the results of $\mathrm{pH}$ and $\mathrm{NO}_{3}$ concentration. For example, SMART2 assumes that there is always equilibrium with secondary $\mathrm{Al}$ compounds. In reality, equilibrium is approached only in the subsoil, while under-saturation prevails in the topsoil. This equilibrium assumption will accelerate the depletion of secondary $\mathrm{Al}$ compounds and will lead to higher $\mathrm{pH}$ and $\mathrm{Al}$ concentrations in the top soil. The $\mathrm{NO}_{3}$ concentration highly depends on the $\mathrm{N}$ mineralisation flux, which in turn depends on the age of the vegetation, vegetation management (e.g. sod cutting, mowing, grazing and tree harvesting), litterfall and $\mathrm{N}$ uptake. These 
aspects have not yet been adequately incorporated in the model for all vegetation structure types. In addition, the effect of $\mathrm{pH}$ on modelled $\mathrm{N}$ mineralisation and $\mathrm{N}$ transformation processes have an inadequate experimental basis (see Additional file 1 Eq. (34)) and MSW (see Additional file 1 Eq. (33)). Our assumption that each vegetation structure type has a particular age strongly influences the model results, as it directly affects litterfall and $\mathrm{N}$ uptake. Furthermore, we assumed that the net biomass production was nil. This was based on the assumption that biomass return to the soil equals biomass production. This shortcoming has been captured by linking SMART2 to the succession model SUMO (Wamelink et al. 2009), but large scale application of SMART2 with SUMO is cumbersome.

\section{Spatial resolution}

Regarding the vertical spatial resolution, we considered the root zone (up to $1 \mathrm{~m}$ thick) as one homogeneous compartment. In validating the results, we used on purpose observations at greater depth, whereas plant species diversity is mainly affected by changes in the topsoil. To model topsoil concentrations, Bonten et al (2011) extended SMART2 to a multi-layer model, however, the regional applicability of this model is low. The spatial resolution of a $250 \times 250 \mathrm{~m}$ grid is too coarse to model ecosystems which forms the topo-sequence within brook valleys, with potentially high nature conservation value. For an adequate modelling of site factors in wetlands and brook valleys, the geographical resolution thus needs to be improved, but the applicability at a national scale of such a modelling approach is low (see e.g. Van Ek et al. 2012).

\section{Conclusions}

The comparison of national scale $\mathrm{pH}$ observations in 1990 with model predictions was good for sandy soils and peat soils (median difference less than 0.2), but $\mathrm{pH}$ values were clearly underestimated (median difference of 0.5 ) for loess and clay soils. Agreements were relatively poor for the $\mathrm{NO}_{3}$ and $\mathrm{NH}_{4}$ concentrations (deviations larger than 50\%). Except for loess soils, median $\mathrm{NO}_{3}$ concentrations were overestimated, especially in poor sandy soils and clay soils.

Reductions in $\mathrm{N}$ and $\mathrm{S}$ deposition and an increase in groundwater level between 1990 and 2030 lead to a moderate increase in $\mathrm{pH}$ (a mean increase with $0.1 \mathrm{pH}$ ) and a strong decrease in $\mathrm{NO}_{3}$ concentration (about $45 \%$ reduction). The strongest increase in $\mathrm{pH}$ is found for grassland $(0.2 \mathrm{pH})$ and the highest decrease in $\mathrm{NO}_{3}$ concentration is found for deciduous forest (49\%).

Projected N deposition reductions in 2030 compared to 2010 (IB-BB scenario, i.e. 13\%) caused relatively small reductions in $\mathrm{NO}_{3}$ concentration (11\%) and hardly any $\mathrm{pH}$ increase in 2030. An increase in groundwater level in 2030 as compared to 2010 (BI-BB scenario) resulted in a comparable decrease in $\mathrm{NO}_{3}$ concentration (11\%), and hardly any increase in $\mathrm{pH}$. The highest decreases in mean $\mathrm{NO}_{3}$ concentration between 2010 and 2030 due to deposition reductions were found for heathland $(15 \%)$ and loess soils (30\%). The highest decreases due to groundwater level increase were found for grassland $(22 \%)$ and for peat soils (38\%) and calcareous soils (20-27\%).

Reductions in N and S deposition between 1990 and 2030 (in practice only changes between 1990 and 2010) resulted in a strongly significant $(p<0.01)$ increase in the mean percentage of target species for all considered vegetation structure types for the $B B$ scenario. In seminatural grassland, there was, however, also a significant increase in competing species. Increase groundwater level ( $B I$ scenario) yields a very significant increase in target species, being relatively highest in heathland, followed by deciduous forest and grassland. Contrary, the deposition reduction between 2010 and 2030 (IB scenario) yields only very minor and non-significant changes. For heathland and deciduous forest, the increase in competing species coincides with a significant increase in competing species. For the II scenario, the largest areas with an increase in target species and the ratio target to competing species occurred in northwestern parts of the Netherlands, areas mainly covered by grassland.

\section{Additional file}

Additional file 1: Supplementary Material, SMART2 Model description, Conversion $\mathrm{pH}$ and nitrate concentration for the Plant diversity Indicator, Areal distribution of soil-vegetation combinations, Input data, Details on the derivation of deposition and hydrology scenarios Nitrogen and sulphur deposition scenarios. (DOCX $578 \mathrm{~kb}$ )

Acknowledgements

This work was financially supported by the Dutch Ministry of Economic Affairs. We are indebted to Sandy van Tol (Netherlands Environmental Assessment Agency) for providing the hydrological scenarios.

\section{Authors' contributions}

JK, JM, GR and W developed and implemented the SMART2 model. GW developed the plant diversity module. JK, JM, GW and AH developed the scenarios, performed the model simulations and evaluated the results. JK and JM drafted the manuscript. All authors read, contributed to and approved the final manuscript.

\section{Competing interests}

The authors declare that they have no competing interests.

\section{Author details}

${ }^{1}$ Wageningen Environmental Research, Wageningen University and Research, P.O. Box 476700 AA Wageningen, The Netherlands. ${ }^{2}$ Netherlands Environmental Assessment Agency, PO Box 3033720 BABilthoven, Wageningen, The Netherlands. ${ }^{3}$ Environmental Systems Analysis Group, Wageningen University and Research, P.O. Box 476700 AA Wageningen, The Netherlands.

Received: 20 September 2016 Accepted: 28 November 2016 Published online: 14 December 2016 


\section{References}

Aerts R, Caluwe H, Beltman B (2003) Is the relation between nutrient supply and biodiversity co-determined by the type of nutrient limitation? Oikos 101(3): 489-498. doi:10.1034/j.1600-0706.2003.12223.x

Bakker JP (1989) Nature management by grazing and cutting. On the ecological significance of grazing and cutting regimes applied to restore former species-rich grassland communities in the Netherlands. Kluwer Academic Publishers, Dordrecht

Belyazid S (2006) Dynamic modelling of biogeochemical processes in forest ecosystems. Doctoral Thesis. Reports in Ecology and Environmental Engineering 2006:1. Department of chemical Engineering, Lund University, Sweden

Bilz M, Kell SP, Maxted N, Lansdown RV (2011) European red list of vascular plants. Publications Office of the European Union, Luxembourg. doi:10. 2779/8515

Bobbink R, Heil GW (1993) Atmospheric deposition of sulphur and nitrogen on heathland ecosystems. In: Aerts R, Heil GW (eds) Heathlands: Patterns and processes in a changing environment., pp 25-50

Bobbink R, Hicks K, Galloway J, Spranger T, Alkemade R, Ashmore M, Bustamante M, Cinderby S, Davidson E, Dentener F, Emmett B, Erisman JW, Fenn M, Gilliam F, Nordin A, Pardo L, de Vries W (2010) Global assessment of nitrogen deposition effects on terrestrial plant diversity: a synthesis. Ecol Appl 20(1): 30-59. doi:10.1890/08-1140.1

Bobbink R, Hornung M, Roelofs JGM (1996) Empirical nitrogen critical loads for natural and semi-natural ecosystems. In: Manual on methodologies and criteria for mapping critical loads/levels. UNECE Convention on Long-range Transboundary Air Pollution. Texte 71-96, III-1/III-54. Umweltbundesamt, Berlin, p 54

Bobbink R, Hornung M, Roelofs JGM (1998) The effects of air-borne nitrogen pollutants on species diversity in natural and semi-natural European vegetation. J Ecol 86(5):717-738. doi:10.1046/j.1365-2745.1998.8650717.x

Bobbink R, Tomassen H, Weijters M, van den Berg L, Strengbom J, Braun S, Nordin A, Schütz K, Hettelingh J-P (2015) Effects and empirical critical loads of nitrogen for Europe. In: De Vries W, Hettelingh J-P, Posch M (eds) Critical Loads and Dynamic Risk Assessments : Nitrogen, Acidity and Metals in Terrestrial and Aquatic Ecosystems, vol 25. Environmental Pollution. Springer, Dordrecht. pp 85-127.

Bonten LTC, Groenenberg JE, Meesenburg H, de Vries W (2011) Using advanced surface complexation models for modelling soil chemistry under forests: Solling forest, Germany. Environ Pollut 159(10):2831-2839. doi:10.1016/j. envpol.2011.05.002

Clark CM, Tilman D (2008) Loss of plant species after chronic low-level nitrogen deposition to prairie grasslands. Nature 451:712-715. doi:10.1038/ nature06503

Dale VH, Joyce LA, McNulty S, Neilson RP, Ayres MP, Flannigan MD, Hanson PJ, Irland LC, Lugo AE, Peterson CJ, Simberloff D, Swanson FJ, Stocks BJ, Michael Wotton B (2001) Climate change and forest disturbances (BioScience). BioScience 51(9):723-734. doi:10.1641/0006-3568(2001)051[0723:ccafd]2.0.co;2

De Vries F, de Groot WJM, Hoogland T, Denneboom J (2003) De bodemkaart van Nederland digitaal : toelichting bij inhoud, actualiteit en methodiek en korte beschrijving van additionele informatie. Alterra-rapport 811, Alterra, Wageningen

De Vries W (1994) Soil response to acid deposition at different regional scales; field and laboratory data, critical loads and model predictions. PhD Thesis. Wageningen University, Wageningen

De Vries W, Klijn JA, Kros J (1994) Simulation of the long-term impact of atmospheric deposition on dune ecosystems in the Netherlands. J Appl Ecol 31(1):59-73

De Vries W, Posch M, Kämäri J (1989) Simulation of the long-term soil response to acid deposition in various buffer ranges. Water Air Soil Pollut 48(3):349390. doi:10.1007/BF00283336

De Vries W, van Grinsven JJM, van Breemen N, Leeters EEJM, Jansen PC (1995) Impacts of acid deposition on concentrations and fluxes of solutes in acid sandy forest soils in the Netherlands. Geoderma 67(1-2):17-43. doi:10.1016/ 0016-7061(94)00056-G

De Vries W, Wamelink GWW, van Dobben H, Kros J, Reinds GJ, Mol-Dijkstra JP, Smart SM, Evans CD, Rowe EC, Belyazid S, Sverdrup HU, van Hinsberg A, Posch M, Hettelingh J-P, Spranger T, Bobbink R (2010) Use of dynamic soilvegetation models to assess impacts of nitrogen deposition on plant species composition: an overview. Ecol Appl 20(1):60-79. doi:10.1890/08-1019.1

Draaijers GPJ, Erisman JW (1993) Atmospheric sulphur deposition to forest stands: throughfall estimates compared to estimates from inference. Atmos Environ 27A(1):43-55. doi:10.1016/0960-1686(93)90069-B
Elser JJ, Bracken MES, Cleland EE, Gruner DS, Harpole WS, Hillebrand H, Ngai JT, Seabloom EW, Shurin JB, Smith JE (2007) Global analysis of nitrogen and phosphorus limitation of primary producers in freshwater, marine and terrestrial ecosystems. Ecol Lett 10(12):1135-1142. doi:10.1111/j.1461-0248. 2007.01113.x

Emmett BA (2007) Nitrogen saturation of terrestrial ecosystems: some recent findings and their implications for our conceptual framework. Water Air Soi Pollut Focus 7(1-3):99-109. doi:10.1007/s11267-006-9103-9

EZ (2012) Beschermde natuur in Nederland: soorten en gebieden in wetgeving en beleid. Ministerie van Economische Zaken. http://www.synbiosys.alterra.nl/ natura2000. Accessed 6 Dec 2012

Galloway JN (1995) Acid deposition: perspectives in time and space. Water Air Soil Pollut 85(1):15-24

Hendriks CMA (1994) De verdrogingstoestand en verdrogingsgevoeligheid van het Nederlandse bos. Staring Centrum Rapport 289, The Winand Staring Centre, Wageningen

Hennekens SM, Schaminée JHJ (2001) TURBOVEG, a comprehensive data base management system for vegetation data. J Veg Sci 12(4):589-591. doi:10. 2307/3237010

Hommel PWFM, Leeters EEJM, Mekkink P, Vrielink JG (1990) Vegetation changes in the Speulderbos (the Netherlands) during the period 1958-1988. Report 23, The Winand Staring Centre, Wageningen.

Klap JM, de Vries W, Leeters EEMM (1999) Effects of acid atmospheric deposition on the chemical composition of loess, clay and peat soils under forest in the Netherlands. Staring Centre Report 97.1, The Winand Staring Centre, Wageningen.

Kleijn CE, Zuidema G, de Vries W (1989) De indirecte effecten van atmosferische depositie op de vitaliteit van Nederlandse bossen. 2. depositie, bodemeigenschappen en bodemvochtsamenstelling van acht Douglasopstanden. Stiboka Rapport 2050. Stichting voor Bodemkartering, Wageningen.

Kros J (1998) Verbetering, verfijning en toepassing van het model SMART2 - De modellering van de effecten van verzuring, vermesting en verdroging voor bossen en natuurterreinen ten behoeve van de Milieubalans, Milieuverkenning en Natuurverkenning. Reeks Milieuplanbureau 3. Winand Staring Centre, Wageningen.

Kros J, de Vries W, Janssen PHM, Bak Cl (1993) The uncertainty in forecasting trends of forest soil acidification. Water Air Soil Pollut 66(1-2):29-58. doi:10. 1007/BF00477059

Kros J, Mol Dijkstra JP, Pebesma EJ (2002) Assessment of the prediction error in a large-scale application of a dynamic soil acidification model. Stoch Env Res Risk A 16(4):279-306

Kros J, Pebesma EJ, Reinds GJ, Finke PA (1999) Uncertainty assessment in modelling soil acidification at the European scale: a case study. J Environ Qual 28(2):366-377

Kros J, Tietema A, Mol-Dijkstra JP, de Vries W (2004) Quantification of nitrate leaching from forest soils on a national scale in the Netherlands. Hydrol Earth Syst Sci 8(4):813-822

Mantilla-Contreras J, Schirmel J, Zerbe S (2011) Influence of soil and microclimate on species composition and grass encroachment in heath succession. J Plant Ecol. doi:10.1093/jpe/rtr031

Olff H, de Leeuw J, Bakker JP, Platerink RJ, van Wijnen HJ, de Munck W (1997) Vegetation succession and herbivory in a salt marsh: changes induced by sea level rise and silt deposition along an elevational gradient. J Ecol 85(6):799-814

Pärtel M (2002) Local plant diversity patterns and evolutionary history at the regional scale. Ecology 83(9):2361-2366. doi:10.1890/00129658(2002)083[2361:LPDPAE]2.0.CO;2

PAS (2015) Programma Aanpak Stikstof 2015-2021. Ministry of Economic Affairs, Ministry of Infrastructure and the Environment, Den Haag.

Pastoors MJH (1993) Landelijk grondwater model; conceptuele modelbeschrijving. RIVM rapport 714305004. RIVM, Bilthoven.

Reinds GJ, Mol-Dijkstra JP, Bonten LTC, Wamelink GWW, Hennekens SM, Goedhart PW, Posch M (2015) Probability of plant species (PROPS) model: latest development. In: Slootweg J, Posch M, Hettelingh J-P (eds) Modelling and Mapping the Impacts of Atmospheric Deposition of Nitrogen and Sulphur. CCE Status Report 2015, RIVM report 2015-0193, Bilthoven, pp. 55-62

Reinds GJ, van Oijen M, Heuvelink GBM, Kros H (2008) Bayesian calibration of the VSD soil acidification model using European forest monitoring data. Geoderma 146(3-4):475-488. doi:10.1016/j.geoderma.2008.06.022

Roelofs JGM, Kempers AJ, Houdijk ALFM, Jansen J (1985) The effect of airborne ammonium sulphate on Pinus nigra var. maritima in the Netherlands. Plant Soil 84(1):45-56. doi:10.1007/BF02197866 
Runhaar J (1999) Impact of hydrological changes on nature conservation areas in the Netherlands. PhD Thesis. Leiden University, Leiden.

Runhaar J, van Walsum PEV, van der Bolt FJE (1999) Natuurgericht Landevaluatiesysteem (NATLES). Rapport 704, Winand Staring Centre, Wageningen.

Sala OE, Chapin FS III, Armesto JJ, Berlow E, Bloomfield J, Dirzo R, Huber-Sanwald E, Huenneke LF, Jackson RB, Kinzig A, Leemans R, Lodge DM, Mooney HA, Oesterheld M, LeRoy Poff N, Sykes MT, Walker BH, Walker M, Wall DH (2000) Global biodiversity scenarios for the year 2100. Science 287:1770-1774. doi: 10.1126/science.287.5459.1770

Smart S, Evans C, Rowe E, Wamelink W, Wright S, Scott A, Roy D, Preston C, Hill $M$, Rothery P (2005) Atmospheric nitrogen pollution impacts on biodiversity: phase 1-model development and testing (CR0289). CEH, Lancaster

Stevens CJ, Dise NB, Mountford JO, Gowing DJ (2004) Impact of nitrogen deposition on the species richness of grasslands. Science 303:1876-1879. doi: 10.1126/science.1094678

Stevens CJ, Manning P, van den Berg LJL, de Graaf MCC, Wamelink GWW, Boxman AW, Bleeker A, Vergeer P, Arroniz-Crespo M, Limpens J, Lamers LPM, Bobbink R, Dorland E (2011) Ecosystem responses to reduced and oxidised nitrogen inputs in European terrestrial habitats. Environ Pollut 159(3):665676. doi:10.1016/j.envpol.2010.12.008

Theurillat J-P, Guisan A (2001) Potential impact of climate change on vegetation in the European Alps: a review. Clim Change 50(1-2):77-109. doi:10.1023/a: 1010632015572

Tilman D (1987) Secondary succession and the pattern of plant dominance along experimental nitrogen gradients. Ecol Monogr 57:189-214

Tilman D (1993) Species richness of experimental productivity gradients: how important is colonization limitation. Ecology 74:2179-2191

Uuttera J, Maltamo M, Kuusela K (1996) Impact of forest management history on the state of forests in relation to natural forest succession-comparative study, north Karelia, Finland vs Republic of Karelia, Russian Federation. Forest Ecol Manage 83(1-2):71-85

Van Amstel AR, Braat LC, Garritsen AC (1989) Verdroging van natuur en landschap in Nederland: beschrijving en analyse. Ministerie van Verkeer \& Waterstaat, Den Haag

Van Andel J, Bakker JP, Grootjans AP (1993) Mechanisms of vegetation succession-a review of concepts and perspectives. Acta Bot Neerl 42(4): 413-433

Van Breemen N, Burrough PA, Velthorst EJ, van Dobben HF, de Wit T, de Ridder TB, Reijnders HFR (1982) Soil acidification from atmospheric ammonium sulfate in forest canopy throughfall. Nature 299:548-550. doi:10.1038/ 299548a0

Van Diggelen R, Molenaar WJ, Kooijman AM (1996) Vegetation succession in a floating mire in relation to management and hydrology. J Veg Sci 7(6):809-820

Van Dobben HF, Wamelink GWW, Schouwenberg EPAG, Mol JP (2002) Use of coupled models to predict biodiversity in managed ecosystems. Rep Ecol Environ Eng 1:76-86

Van Dobben HF, Wamelink GWW, Slim PA, Kamiński J, Piórkowski H (2016) Species-rich grassland can persist under nitrogen-rich but phosphoruslimited conditions. Plant Soil. 1-16. doi:10.1007/s11104-016-3021-z

Van Ek R, Janssen G, Kuijper M, Veldhuizen A, Wamelink W, Mol J, Groot A, Schippers P, Kroes J, Supit I, Simmelink E, van Geer F, Janssen PHM, van der Sluis J, Bessembinder J (2012) NMDC-Innovatieproject. Van Kritische zone tot Kritische Onzekerheden: case studie Baakse beek. rapport 1205952, Deltares, Delft.

Van Wirdum G (1991) Vegetation and hydrology of floating rich-fens. PhD Thesis. University of Amsterdam, Amsterdam

Wamelink GWW, Goedhart PW, Malinowska AH, Frissel JY, Wegman RJM, Slim PA, van Dobben HF (2011) Ecological ranges for the $\mathrm{pH}$ and $\mathrm{NO}(3)$ of syntaxa: a new basis for the estimation of critical loads for acid and nitrogen deposition. J Veg Sci 22(4):741-749. doi:10.1111/j.1654-1103.2011.01286.x

Wamelink GWW, Goedhart PW, Van Dobben HF, Berendse F (2005) Plant species as predictors of soil $\mathrm{pH}$ : replacing expert judgement with measurements. J Veg Sci 16(4):461-470

Wamelink GWW, ter Braak CFJ, van Dobben HF (2003) Changes in large-scale patterns of plant biodiversity predicted from environmental economic scenarios. Landscape Ecol 18(5):513-527

Wamelink GWW, van Adrichem MHC, van Dobben HF, Frissel JY, den Held M, Joosten V, Malinowska AH, Slim PA, Wegman RMA (2012) Vegetation relevés and soil measurements in the Netherlands: the Ecological Conditions
Database (EC). Vegetation databases for the 21st century, vol Biodiv Ecol. 4. doi:10.7809/b-e.00067

Wamelink GWW, van Dobben HF, Berendse F (2009) Vegetation succession as affected by decreasing nitrogen deposition, soil characteristics and site management: a modelling approach. Forest Ecol Manage 258(8):1762-1773. doi:10.1016/j.foreco.2009.05.043

Wassen MJ, Olde Venterink H, Lapshina ED, Tanneberger F (2005) Endangered plants persist under phosphorus limitation. Nature 437:547-550. doi:10.1038/ nature03950

Xiankai L, Jiangming M, Shaofeng D (2008) Effects of nitrogen deposition on forest biodiversity. Acta Ecol Sinica 28(11):5532-5548, doi:10.1016/S18722032(09)60012-3.

\section{Submit your manuscript to a SpringerOpen ${ }^{\circ}$ journal and benefit from:}

- Convenient online submission

- Rigorous peer review

- Immediate publication on acceptance

- Open access: articles freely available online

- High visibility within the field

- Retaining the copyright to your article

Submit your next manuscript at springeropen.com 